\title{
Strategies for Optimizing the Production of Proteins and Peptides with Multiple Disulfide Bonds
}

\author{
Yunqi Ma, Chang-Joo Lee and Jang-Su Park *(D) \\ Department of Chemistry and Chemistry Institute of Functional Materials, Pusan National University, \\ Busan 609-735, Korea; michell@pusan.ac.kr (Y.M.); gd0090s@naver.com (C.-J.L.) \\ * Correspondence: jaspark@pusan.ac.kr; Tel.: +82-51-510-2294; Fax: +82-51-516-7421
}

Received: 5 August 2020; Accepted: 25 August 2020; Published: 26 August 2020

\begin{abstract}
Bacteria can produce recombinant proteins quickly and cost effectively. However, their physiological properties limit their use for the production of proteins in their native form, especially polypeptides that are subjected to major post-translational modifications. Proteins that rely on disulfide bridges for their stability are difficult to produce in Escherichia coli. The bacterium offers the least costly, simplest, and fastest method for protein production. However, it is difficult to produce proteins with a very large size. Saccharomyces cerevisiae and Pichia pastoris are the most commonly used yeast species for protein production. At a low expense, yeasts can offer high protein yields, generate proteins with a molecular weight greater than $50 \mathrm{kDa}$, extract signal sequences, and glycosylate proteins. Both eukaryotic and prokaryotic species maintain reducing conditions in the cytoplasm. Hence, the formation of disulfide bonds is inhibited. These bonds are formed in eukaryotic cells during the export cycle, under the oxidizing conditions of the endoplasmic reticulum. Bacteria do not have an advanced subcellular space, but in the oxidizing periplasm, they exhibit both export systems and enzymatic activities directed at the formation and quality of disulfide bonds. Here, we discuss current techniques used to target eukaryotic and prokaryotic species for the generation of correctly folded proteins with disulfide bonds.
\end{abstract}

Keywords: multiple disulfides; expression optimization; leading protein; signal peptide; yeast; high yield

\section{Introduction}

Proteins play a major role in cell signaling, inflammatory reactions, cell adhesion, and cell cycle. Commercially, they are primarily produced with the aid of genetic and protein engineering [1]. Native and recombinant proteins are used in a wide range of areas in the biopharmaceutical, enzyme, and agricultural industries. Such molecules are increasingly being used in the fields of pharmacy, diagnostics, milk, diet, detergents, textiles, clothing, paper, pulp, polymers, and plastics [2-6].

In conventional biotechnology, cells have been used for several processes. Across all genetics and molecular biology revolutions to date, recombinant protein processing is a significant method that requires the use of cells, and it is a state-of-the-art method for pharmaceutical protein processing and screening [6]. The bioprocess for recombinant protein production (Figure 1) is divided into upstream and downstream sequences: The cells are fermented before and during protein production (upstream), and the product is either excreted from the cells into the culture medium or the cells are lysed and the cell lysates are processed further (downstream) [7]. Downstream processes may include the separation of soluble and insoluble cell debris and media components, protein purification, protein formulation (including concentration), bioconjugation, protein-bioconjugate purification, and protein refolding. Only one downstream process is required depending on the protein and its specific requirements [8]. Proteins are susceptible to denaturation by several factors, such as $\mathrm{pH}$, salt concentration, organic 
solvents, shearing, surface and interface interaction (including the formation of protein aggregates), lyophilization, moisture levels, protein concentration, and temperature changes. Therefore, such processes need to be carefully engineered to generate intact and functional proteins [9,10].

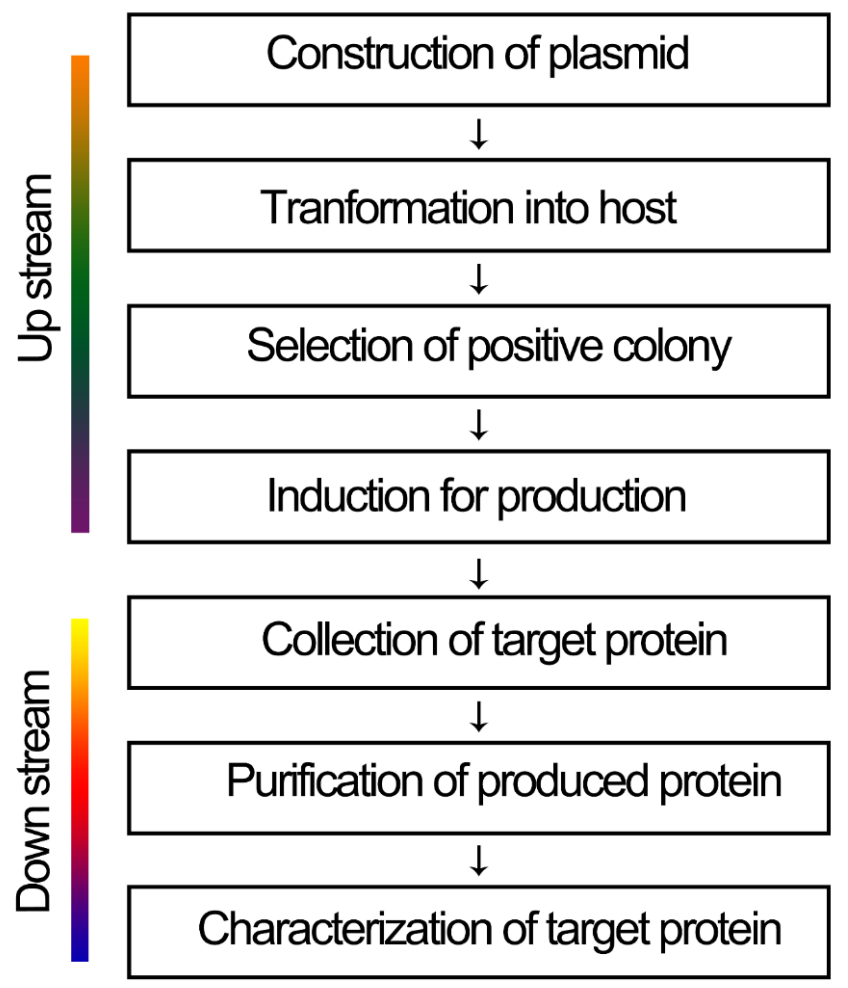

Figure 1. Recombinant protein production process. The process includes upstream and downstream.

Large proteins (usually more than 400 amino acids) are typically expressed in a eukaryotic system, whereas smaller ones are expressed in prokaryotic systems. Mammalian cells, fungi, or the baculovirus system are typically chosen for proteins requiring glycosylation. The least expensive, simplest, and fastest protein expression can be achieved in Escherichia coli. Nonetheless, large proteins are difficult to be synthesized with this bacterium. Moreover, E. coli is not the best system for S-S-rich proteins that require post-translational modifications. Saccharomyces cerevisiae and Pichia pastoris are the most frequently used yeast species for the production of such proteins. At a low cost, yeast systems typically generate high protein yields as well as proteins with a molecular weight greater than $50 \mathrm{kDa}$, along with the extraction of signal sequences and stimulation of glycosylation. The baculovirus system can incorporate more complex post-translational protein modifications. Most commonly, mammalian cells are used for the production of recombinant mammalian glycosylated proteins. Genetically engineered animals secrete recombinant proteins in their milk, blood, or urine. Similarly, several recombinant proteins can be produced from transgenic plants, such as Arabidopsis thaliana.

The effectiveness of expressing a recombinant protein in E. coli primarily relies on the ability to prevent unfavorable interactions between newly expressed polypeptides. These interactions lead to the aggregation of intermediate folding substances instead of native protein production [6-8,11]. System efficiency can be improved by maintaining conditions that stabilize intermediate folding and promote mature structure formation. Various strategies can help prevent the aggregation of proteins by masking the hydrophobic patches on their external surfaces [12,13]. Such strategies involve the introduction of chaperone molecules, incorporation of detergents, or co-expression of interacting sub-units involved in large complexes. When the conditions are designed to maintain the mono-dispersion of the folding intermediates, speeding up the folding cycle becomes essential for the production of stable native structures and prevention of the accumulation of metastable 
configurations that are potentially vulnerable to aggregation [14]. Foldases and isomerases may improve the folding process considerably. In this review, we focus on the solutions that are available for improving the bacterial expression of proteins that rely on the formation of disulfide bonds in their native state. Such Cys-Cys bridges (Figure 2) block folding units into stable conformations by covalently linking residues, and their formation is necessary for the stable tertiary structure of a protein [15]. The equilibrium between reduced and oxidized cysteines is regulated by the redox conditions of cellular compartments. In eukaryotic cells, the endoplasmic reticulum (ER) is the oxidative environment in which disulfide bonds are preferentially formed [16]. Therefore, to complete their folding, polypeptides expressed in the reducing cytoplasm must be guided to the ER. The targeting of the subcellular compartment is facilitated by signal peptides fused to the amino terminal of the protein that are removed after the protein is imported into the organelle. Prokaryotes share key features of the reducing cytoplasm with the eukaryotic cells but do not exhibit structures that mimic the ER. Instead, they possess an oxidizing periplasm in which pro-peptides can be translocated with an extra $\mathrm{N}$-terminal export peptide. Therefore, the expression of a eukaryotic protein in the bacterial periplasm is possible after replacing the ER with a bacterial signal sequence for translocation to the periplasm. Alternative approaches include encouraging the formation of disulfide bonds by targeting nascent polypeptides to the external medium or changing the redox conditions in the cytoplasm to a moderate oxidizing state $[16,17]$. Overexpression and direct fusion to chaperones, foldases, and stabilizing carriers have been studied to achieve an increase in the yields of functional proteins. Finally, in chaotropic solutions, protein aggregates can be dissolved first to achieve a monodispersed state and then used as a starting material for oxidative refolding processes.

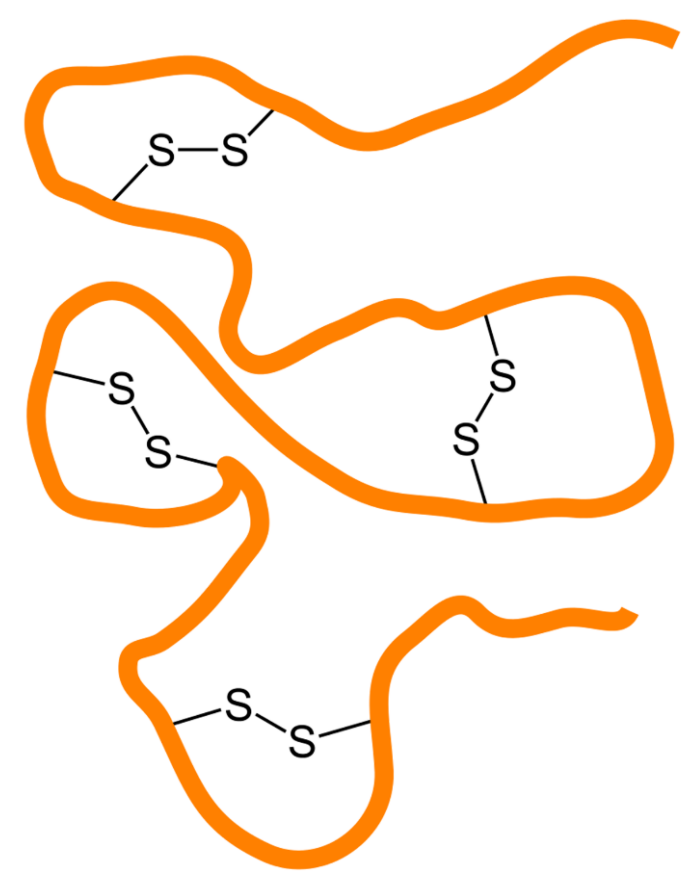

Figure 2. Schematic of disulfide bonds crosslinking regions of a protein.

\section{Host Strains for the Overexpression of Target Proteins}

The methylotrophic yeast, P. pastoris, is a useful system for the production of genetically engineered enzymes (through heterologous gene expression) for both research and industrial purposes [18]. It is considered non-toxigenic and non-pathogenic, and the Food and Drug Administration (FDA, White Oak, MD, USA) has approved several products prepared with help of this organism, and these products are generally accepted as safe substances (GRAS). In addition, it is an excellent host for the synthesis of recombinant proteins and offers additional benefits ranging from rapid growth to high cell density 
in an inexpensive and non-complex culture medium and facilitates the purification of recombinant proteins expressed heterologically [19-21].

E. coli expression systems are often used to produce exogenous protein on laboratory and industrial scales owing to the low cost, speed, and simplicity of cultivation [22]. E. coli strains DH5 $\alpha$ and Rosetta (DE3) have been used for the cloning of genes and the expression of proteins. E. coli is one of the earliest and most commonly used hosts for heterologous protein production $[23,24]$. The advantages and disadvantages are presented in Table 1 . The advantages include rapid growth, fast expression, ease of cultivation, and high product yields [25-27]. It is used to manufacture large quantities of commercialized proteins. This method is particularly outstanding for the functional expression of non-glycosylated proteins. E. coli genetics are better understood than that of any other microorganism [28]. Recent advances in the understanding of the processes involved in coding, translation, and protein folding in E. coli and the use of advanced genetic instruments render this bacterium more useful than ever for the production of diverse eukaryotic proteins [29-32]. Its genome can be updated rapidly and reliably with ease. The regulation of promoter elements is not complex, and the number of plasmid copies can be easily adjusted. This method often adjusts the metabolic carbon supply, prevents the absorption of amino acid analogs, establishes intracellular disulfide bonds [33], and demonstrates a reproducible performance with computer control. E. coli can produce recombinant proteins with up to $80 \%$ of its dry weight and withstand many environmental conditions [34].

Table 1. Characteristics of Escherichia coli expression systems.

\begin{tabular}{cc}
\hline Advantages & Disadvantages \\
\hline Rapid expression & Proteins with disulfide bonds are difficult to express \\
High yields & Production of unglycosylated proteins \\
Ease of culture and genome modifications & Proteins with endotoxins are produced \\
Inexpensive & Acetate formation results in cell toxicity \\
Rapid mass production and cost-effective & Proteins produced as inclusion bodies are inactive; \\
& thus, refolding is required. \\
\hline
\end{tabular}

Human insulin-like growth factor (hIGF-I) is a single-chain 70-residue therapeutic protein with three disulfide bonds within its structure. IGF-I affects cell proliferation, differentiation, and apoptosis in the long term. E. coli promotes the production of this kind of protein through its relative ease, low cost, and accelerated high-density cultivation. Therefore, it played an important role in the pharmaceutical industry in the last decades.

However, E. coli has several disadvantages that need to be addressed for efficient protein production. High cell densities cause toxicity owing to the deposition of acetates [35-37]. This can be inhibited by monitoring oxygen levels. Proteins that are generated as inclusion bodies are often inert, insoluble, and require refolding. Owing to the limitation associated with the processing of proteins with multiple disulfide bonds, it is extremely difficult to refold such proteins [38,39]. The E. coli system generates unmodified proteins without glycosylation. Hence, some of the antibodies that are synthesized do not recognize mammalian proteins [40-42]. Interestingly, the non-glycosylated human tPA produced in E. coli was fully active in vitro. Given the absence of glycosylation, the drug exhibited a four-fold longer plasma half-life and a correspondingly higher clearance rate in animals [43,44]. The resulting quantity constituted $5-10 \%$ of total E. coli protein. To improve the process in E. coli, the following measures have been used: (i) Use of multiple promoters to control expression; (ii) use of specific host strains; (iii) co-expression of chaperones and/or foldase; (iv) reduction of temperature; (v) secretion of proteins in the periplasmic space or medium; (vi) reduction of protein synthesis; (vii) shift of the growth medium; (viii) introduction of a fusion partner; (ix) release of a protein fragment; and (x) denaturation and refolding of the protein in vitro [45]. Rapid fermentation with a cell density of $E$. coli has resulted in dry cell contents ranging from 20 to $175 \mathrm{~g} / \mathrm{L}$ [46]. The issue of acetate development and toxicity can be solved by exponentially feeding glucose in the media and maintaining the real rate of growth below 
which the development of acetate is obtained. Yields as high as $5.5 \mathrm{~g} / \mathrm{L}$ of $\alpha$-consensus interferon have been achieved in the broth [47]. Long-term development of the chemostat (219 generations below a dilution rate of $0.05 \mathrm{~h}^{-1}$ ) produced an $E$. coli mutant with an increased growth rate and biomass yields, shorter lag period, lower acetate production, and increased stress resistance [48]. This strain produced high yields of heterologous secreted proteins [49]. Heterologous proteins developed as inclusion bodies in E. coli are inert, composite, and insoluble and typically exhibit non-native intraand inter-molecular disulfide bonds and rare free cysteines [50]. Such bodies must be separated from the cell to derive the active protein along with the proteins solubilized by denaturants, and disulfide bonds must be extracted using reduction agents. Refolding is achieved by eliminating the denaturant and reducing agent, accompanied by the protein being renatured. Heterologous recombinant proteins may be formed in a highly soluble biologically active form when their genomes are fused to the E. coli genes with thioredoxin [51]. Few fusions maintain the properties of thioredoxin that are produced by the methods of osmotic shock or freeze/thaw, along with strong thermal stability. Thioredoxin has a low molecular size (11 kDa) and is typically derived in a soluble form at $40 \%$ of the total cell protein [52]. Another effective approach for the development of inclusion bodies that comprise heterologous proteins is to lower the growth temperature from 37 to $30{ }^{\circ} \mathrm{C}[53,54]$. Higher yields are usually obtained in the cytoplasm than in the periplasmic space [55]. It is necessary to export cytoplasmic proteins for the ease of the purification process and promote proper folding. This can be achieved with proteins comprising disulfide bonds since the cytoplasm eliminates an atmosphere to a great extent [56]. The fusion is achieved with a leader peptide at the N-terminal to secrete certain proteins into the periplasm. Osmotic shock or cell wall permeabilization is used to draw the proteins out of the periplasm and into the medium [57]. A mechanism involving regulation with promoter elements (lac, tac, and trc) is employed to increase the output. Promoter structures need to be defined and closely controlled to achieve a low-basal speech quality and must be easily transferable to other E. coli strains that require a simple and inexpensive induction technique, independent of the medium ingredients [58].

The secretion of recombinant proteins by $E$. coli into the periplasm or extracellular medium has several benefits over intracellular development as inclusion bodies. It improves packaging, folding, and in vivo downstream stability and enables the manufacture of soluble active proteins at reduced processing costs [59-62].

Lactic acid bacteria (LAB) comprise a large community of Gram-positive microorganisms, including members of the genera Lactococcus, Lactobacillus, Pediococcus, Streptococcus, Leuconostoc, and Oenococcus, that are used for different applications. Most of these bacteria, which have been used in food production for a long time, are deemed suitable for human consumption, and thus have GRAS status $[63,64]$. Owing to its simple handling, sequenced genome, and the advancement of genetic techniques in recent years, Lactococcus lactis is the best described species of this group and is characterized as the model organism. This has rendered L. lactis more suitable for biotechnological uses, ranging from recombinant protein development to the expression and distribution of antigens and bioactive polypeptides to mucosal surfaces [65], and more recently, as a distribution system for DNA vaccines [66].

Yeasts, the single-celled eukaryotic fungal cells, are also used for the development of recombinant proteins that are not well developed in E. coli owing to folding issues or the glycosylation requirements [67-69]. The major advantages of yeast expression systems are listed in Table 2. The yeast strains are genetically well defined, and several post-translation modifications have been identified [70]. They are easy to handle, less costly than insect or mammalian cells, and well suited for the fermentation processes [71]. The two most utilized yeast strains are S. cerevisiae and the methylotrophic yeast $P$. pastoris [72]. Specific populations of yeasts have proved to be useful in the production and study of recombinant eukaryotic proteins. Some proteins produced in different host strains are listed in Table 3. For instance, on A. niger, glucose oxidase can be generated by S. cerevisiae at $9 \mathrm{~g} / \mathrm{L}$. S. cerevisiae provides certain benefits as a cloning host over bacteria: (i) Traditionally, they have been used in industrial fermentation; (ii) when sufficient signal sequences have been attached to the 
structural genes, they can secrete heterologous proteins into the extracellular broth; and (iii) they perform protein glycosylation [73-77]. However, glycosylation performed by S. cerevisiae is sometimes unfavorable for the production of mammalian proteins as O-linked oligosaccharides often include mannose, whereas higher eukaryotic proteins produce sialylated O-linked chains [78,79]. In addition, the yeast over-glycosylates $\mathrm{N}$-linked sites, which leads to reduced activity and receptor binding and may trigger an immune reaction [80]. Marketed items that are manufactured with S. cerevisiae include insulin, hepatitis B surface antigen, urate oxidase, glucagons, granulocyte-macrophage colony-stimulating factor (GM-CSF), hirudin, and platelet-derived growth factor [81,82].

Table 2. Advantages of yeast expression systems.

\begin{tabular}{|c|c|}
\hline Advantages & Disadvantages \\
\hline $\begin{array}{c}\text { High yield } \\
\text { Stable production strains } \\
\text { Durability } \\
\text { Cost-effective } \\
\text { High-density growth } \\
\text { High productivity } \\
\text { Suitable for isotopically labeled protein production } \\
\text { Rapid growth in chemically defined media } \\
\text { Product processing similar to mammalian cells } \\
\text { Can handle S-S-rich proteins } \\
\text { Can assist in protein folding } \\
\text { Can glycosylate proteins }\end{array}$ & $\begin{array}{c}\text { N or O-linked glycosylation pattern } \\
\text { (different from higher eukaryote) } \\
\text { Hypermannosylation } \\
\text { Proteolytic degradation }\end{array}$ \\
\hline
\end{tabular}

Table 3. Host strains and the produced recombinant proteins in them.

\begin{tabular}{ccc}
\hline Host & Recombinant Protein & Reference \\
\hline E. coli & venom proteins & {$[83,84]$} \\
P. pastoris & lipase r27RC & {$[85]$} \\
S. cerevisiae & rat protein disulfide isomerase & {$[86]$} \\
L. lactis & Merozoite antigens & {$[87]$} \\
\hline
\end{tabular}

Almost all eukaryotic polypeptides that are secreted are glycosylated. Glycosylation is species-, tissue- and cell-type specific $[88,89]$. In certain conditions, a protein that is typically glycosylated is activated in the absence of the carbohydrate moiety, which may be rendered in bacteria [90]. For proteins in which glycosylation is necessary for stabilization or proper folding (e.g., erythropoietin and human chorionic gonadotropin), recombinant yeast, mold, insect, or mammalian cells can be used. Mammalian cell-secreted proteins are glycosylated with D-mannose sugars covalently bound to asparagine-linked N-acetyl-D-glucosamine molecules [91,92]. Secreted fungal enzymes also exhibit the same glycosylation form [93], although additional carbohydrates connected to serine or threonine oxygen are often present in fungal proteins [94-97].

The glycosylation of a protein can differ from others based on factors, such as the medium used for culturing the cells. Glycosylation determines the kinetics of the reaction (if the protein is an enzyme), solubility, half-life serum, thermal stability, in vivo functions, immunogenicity, and binding receptors. Galactosylated enkephalins are 1000-10,000 times more soluble in peptides than the peptide alone $[98,99]$. The cloning of genes that encode bacterial non-glycosylated proteins in yeast results in the enhanced stability of proteins by glycosylation. The proteins produced in the yeast are glycosylated and more stable $[100,101]$. Glycosylation also influences the pharmacokinetics of the protein (residence time in vivo) [102-104]. Methods of improving the stability protect against the proteolytic assault on erythropoietin (EPO) by terminal sialic acid [105], tissue plasminogen activator (TPA) [106], and interferons. Human EPO is 1000 times more active in vivo than its desialylated form; however, both forms demonstrate identical in vitro activities [107]. Cloned glycosylated transferases 
will be used in the future to maintain homogeneity ("glycosylation engineering"). As hosts for the industrial development of recombinant proteins, methylotrophic yeasts have become considerably desirable, as promoters regulating the expression of genes are among the best owing to their tight control of such genes. The cells themselves can be rapidly cloned to large densities, and the degree of product expression can be controlled by basic medium manipulation. Methylotrophic yeasts can grow to a maximum density of $130 \mathrm{~g} / \mathrm{L}[108,109]$. The four recognized methylotrophic yeast genera (Hansenula, Pichia, Candida, and Torulopsis) share a specific metabolic mechanism that enables them to use methanol as their primary source of energy. Several enzymes are rapidly synthesized at high rates in a transcriptionally controlled reaction for methanol production. The ability to form disulfide bonds and protein glycosylation is the biggest advantage of Pichia over E. coli. In cases where disulfides are required, E. coli generates an inactive or insoluble protein that is misfolded. Compared with other expression systems, such as Drosophila melanogaster S2-cells or Chinese hamster ovary $(\mathrm{CHO})$ cells, Pichia normally results in much higher yields. Cell lines derived from multicellular organisms typically need complex (rich) media, thereby increasing the cost of protein content processing. In addition, since Pichia can be produced in media containing only one source of carbon and one source of nitrogen, it is ideal for isotopic labeling applications, such as for performing protein NMR. Methylotrophic P. pastoris and its excellent capacity of protein secretion is a significant benefit for the production of recombinant proteins, as opposed to other yeasts. Progress has been achieved by genetically engineering the secretory system of P. pastoris for the production of human N-glycosylated proteins. Glycosylation is less extensive in P. pastoris than in S. cerevisiae due to the shorter chain lengths of $\mathrm{N}$-linked high-mannose oligosaccharides, usually up to 20 residues compared to 50-150 residues in S. cerevisiae. P. pastoris also lacks $\alpha$-1, 3-linked mannosyl transferase that produces $\alpha$-1, 3-linked mannosyl terminal linkages in S. cerevisiae and leads to a highly antigenic response in patients. Hirudin, a thrombin inhibitor derived from the medicinal leech Hirudo medicinalis, is now produced by the recombinant yeast, P. pastoris, which produces high levels of mammalian recombinant proteins in the extracellular medium. An insulin precursor was produced at $1.5 \mathrm{~g} / \mathrm{L}$. Other studies demonstrate the production of $4 \mathrm{~g} / \mathrm{L}$ of intracellular interleukin 2 at $30 \%$ of the total protein, $4 \mathrm{~g} / \mathrm{L}$ of secreted human serum albumin, $6 \mathrm{~g} / \mathrm{L}$ of tumor necrosis factor and other heterologous proteins, and $10 \mathrm{~g} / \mathrm{L}$ of tumor necrosis factor. The production of serum albumin in S. cerevisiae amounted to $0.15 \mathrm{~g} / \mathrm{L}$, whereas the titer was $10 \mathrm{~g} / \mathrm{L}$ in P. pastoris. P. pastoris produced gelatin at over $14 \mathrm{~g} / \mathrm{L}$. It also yielded $300 \mathrm{mg} / \mathrm{L} /$ day of recombinant human chitinase. Intracellular tetanus toxin fragment $C$ was produced as $27 \%$ of the total protein with a titer of $12 \mathrm{~g} / \mathrm{L}$. Claims have been made that $P$. pastoris can produce $20-30 \mathrm{~g} / \mathrm{L}$ of recombinant proteins. However, certain disadvantages have been associated with the use of Pichia as a host for heterologous expression. Many proteins require chaperonins for proper folding, which Pichia is unable to produce. Gerngross and colleagues managed to create a strain that produces EPO in its normal glycosylated form derived from humans. This was achieved by exchanging the enzymes responsible for the yeast form of glycosylation with the mammalian homologs. Thus, the altered glycosylation pattern allowed the protein to be fully functional in humans. Since then, glycosylation of recombinant proteins resulting in the human subtype that is produced in the engineered P. pastoris has also been demonstrated with other human proteins. Heterologous gene expression in another methylotroph, Hansenula polymorpha, yielded $1 \mathrm{~g} / \mathrm{L}$ of intracellular hepatitis B S-antigen (50 gene copies/cell), 1.4 g/L of secreted glucoamylase (4 copies/cell), and $13.5 \mathrm{~g} / \mathrm{L}$ of phytase. Secreted mammalian proteins can be produced at $3 \mathrm{~g} / \mathrm{L}$ by L. lactis.

\section{Location of Expression}

In principle, recombinantly expressed proteins can be directed to three different locations, namely, the cytoplasm, periplasm, or cultivation medium. Various advantages and disadvantages are associated with the direction of a recombinant protein to a specific cellular compartment (Table 4). Typically, expression in the cytoplasm is preferable as the resultant production yields are high. Disulfide bond formation is segregated in E. coli and is actively catalyzed in the periplasm by the 
Dsb system. The reduction of cysteines in the cytoplasm is achieved by thioredoxin and glutaredoxin. Thioredoxin is maintained in the reduced state by thioredoxin reductase $(\operatorname{trx} B)$, while glutaredoxin is maintained by glutathione. The low-molecular-weight glutathione molecule is reduced by glutathione reductase. The disruption of the $\operatorname{tr} x B$ and gor genes that encode the two reductases allows the formation of disulfide bonds in the $E$. coli cytoplasm. The trxB and trxB/gor-negative strains of $E$. coli have been selected for the expression of several proteins. Folding and disulfide bond formation in the target protein is enhanced by fusion to thioredoxin in the strains that lack trxB. The overexpression of the periplasmic foldase, DsbC, in the cytoplasm further stimulates disulfide bond formation. Transmembrane transport is typically mediated by $\mathrm{N}$-terminal signal peptides by directing the protein to a specific transporter complex in the membrane. Most proteins are exported across the inner membrane into the periplasm by the well-known Sec translocase apparatus. Frequently used periplasmic leader sequences are derived from ompT, ompA, pelB, phoA, malE, lamB, and lactamase for potential export. Systems are available for the potential export and enhanced disulfide bond formation achieved by fusion to DsbA or DsbC, which are the enzymes catalyzing disulfide bond formation and isomerization in the periplasm. A direct consequence of periplasmic production is a considerable reduction in the amount of contaminating proteins in the starting material used for purification [110]. Other benefits include a much higher probability for obtaining an authentic $\mathrm{N}$-terminal in the target protein, decreased proteolysis, and simplified protein release achieved by osmotic shock procedures. Efficient pathways for translocation via the outer membrane are not known, although certain proteins that are exported to the periplasm diffuse or leak into the extracellular medium. Passive transport across the outer membrane can be stimulated by external or internal destabilization of the structural components of E. coli [111-113]. Destabilization is achieved either by the lysis of proteins functioning at the interior of the cell using strains lacking structural membrane components or permeabilization directed from the cell exterior either mechanically, enzymatic, or chemically. Another strategy involves engineering secretion mechanisms in E. coli by using either pathogenic E. coli or other species. The direction of recombinant proteins into the periplasm often results in the leakage of protein into the extracellular cultivation medium. This uncontrolled strategy enables the purification of potato carboxypeptidase inhibitor and cholera toxin B subunit. The ompA signal sequence has been recently used to translocate a recombinant peptide to the periplasm for secretion into the cultivation medium. Translocation was enhanced by the co-expression of two secretion factors along with an increase in the level of the recombinant peptide in the cultivation medium $[114,115]$. Recombinant proteins probably exit the periplasm passively via destabilized membrane structures, either upon cellular aging or a change in the culture conditions. However, detailed information and standardization methods for directed secretion remain unknown.

Table 4. Advantages and disadvantages of different locations of expression.

\begin{tabular}{ccc}
\hline & Advantage & Disadvantage \\
\hline Cytoplasmic & $\begin{array}{c}\text { Higher expression level, simple } \\
\text { plasmid construction }\end{array}$ & $\begin{array}{c}\text { Inclusion body may be formed, unfavorable } \\
\text { conditions for S-S bond formation, } \\
\text { higher proteolysis }\end{array}$ \\
\hline Periplasmic & $\begin{array}{c}\text { Less proteolysis, improved } \\
\text { folding, simple purification }\end{array}$ & $\begin{array}{c}\text { Inclusion body may be formed, the signal does not } \\
\text { always facilitate export }\end{array}$ \\
\hline Extracellular & $\begin{array}{c}\text { Least extensive proteolysis, } \\
\text { simpler purification (fewer protein } \\
\text { species), improved folding }\end{array}$ & $\begin{array}{c}\text { Usually no secretion is observed, purification may } \\
\text { be complex (protein dilution) }\end{array}$ \\
\hline
\end{tabular}

\section{Vector Selection for Expression}

Vector pcDNA3(-) (purchased from sigmaaldrich, Seoul, Korea South) and fusion gene were injected into the $\mathrm{pET}$ sequence to generate vectors for the target protein. Many genomes that were used in this analysis were designed using a similar technique. All vectors were based on the pET vector series. The propagation and amplification of the vectors were accomplished using normal 
techniques [116,117]. To maximize the usage of restriction locations, we decided to create two different plasmids for heavy- and light-chain expression (some vectors we used are listed in Table 5), as many sites that are rare in $\mathrm{VH}$ are common in VL and vice versa [118]. However, by cloning the light-chain transcription unit into the VH express backbone using HindIII and KpnI or EcoRI, a single plasmid was formed that comprised all Ig transcription units (in either orientation with respect to each other).

Table 5. Vectors based on different promoters used for heterologous protein production and their characteristics.

\begin{tabular}{|c|c|c|c|}
\hline Vector & Induction (IPTG) & Level of Expression & Key Feature \\
\hline lac & $0.2 \mathrm{mM}$ & $\begin{array}{l}\text { Low to moderate levels; } \\
15-30 \% \text { of total } \\
\text { cell proteins }\end{array}$ & $\begin{array}{l}\text { Weak, regulated, suitable for gene } \\
\text { products at very low intracellular level; } \\
\text { comparatively expensive induction }\end{array}$ \\
\hline Trc and tac & $0.2 \mathrm{mM}$ & Moderately high & $\begin{array}{l}\text { High-level, but lower than T7 system; } \\
\text { regulated expression still possible; } \\
\text { comparatively expensive induction; } \\
\text { high basal level }\end{array}$ \\
\hline $\begin{array}{c}\text { T7 RNA } \\
\text { polymerase }\end{array}$ & $0.2 \mathrm{mM}$ & $\begin{array}{l}\text { Very high; } \\
40-50 \% \text { of total } \\
\text { cell proteins }\end{array}$ & $\begin{array}{l}\text { Utilizes T7 RNA polymerase; high-level } \\
\text { inducible overexpression; T7lac system } \\
\text { for tight control of induction needed for } \\
\text { more toxic clones; relatively expensive } \\
\text { induction; basal level depends on } \\
\text { used strain (pLys) }\end{array}$ \\
\hline Phage promoter $\mathrm{P}_{\mathrm{L}}$ & $\begin{array}{l}\text { Shifting the temperature } \\
\text { from } 30 \text { to } 42{ }^{\circ} \mathrm{C}\left(45^{\circ} \mathrm{C}\right)\end{array}$ & Moderately high & $\begin{array}{c}\text { Temperature-sensitive host required; } \\
\text { lower likelihood of "leaky" } \\
\text { non-induced expression; basal level, } \\
\text { high basal level by temperatures } \\
\text { below } 30^{\circ} \mathrm{C}\end{array}$ \\
\hline
\end{tabular}

\section{Signal Peptide in Fusion Expression}

A well-designed vector for the prokaryotic expression involves a collection of optimally arranged genetic elements that influence both transcriptional and translational aspects of protein development. Additionally, the presence of an antibiotic-resistance gene promotes phenotypic vector collection, and the center of replication (Ori) defines the number of vector copies [119]. The secretion of proteins via the extracellular matrix might be a suitable technique. Similar to that in E. coli, this compartment exhibits the lowest degree of proteolytic activity and the purification of the potentially soluble structurally accurate protein can be significantly improved due to the presence of a few contaminating bacterial proteins. Unfortunately, this technique is not feasible for the large-scale processing of heterologous proteins in E. coli [120]. Proteins that are supposed to be secreted into the extracellular medium may traverse two separate membrane boundaries, namely, the cytoplasmic and the outer membranes [121]. Our knowledge of the molecular mechanisms that regulate membrane translocation, especially via the outer membrane, remains incomplete. Strategies for protein secretion in the culture medium usually fall into two categories: The use of known pathways for secreted proteins and the use of signal sequences, fusion partners, and permeabilizing agents that affect protein secretion owing to selective and restricted external membrane permeability. Protein yields corresponding to both approaches are typically low.

According to Fontaine's explanation, the mechanism involving YkgR, which is one of the tiny transmembrane proteins, might be consistent with the transport mechanism of the Sec or YidC pathway. It can also be directed between the inner and outer membranes [122]. As shown in Figure 3, throughout the inner membrane, YkgR continues to translocate with the N-terminal centered in the cytoplasm and C-terminal centered in the periplasm. The YkgR tag can also be expressed at a high level in the periplasm. Therefore, the hypothesis of combining the $\mathrm{YkgR}$ tag with the target protein has been proposed. 


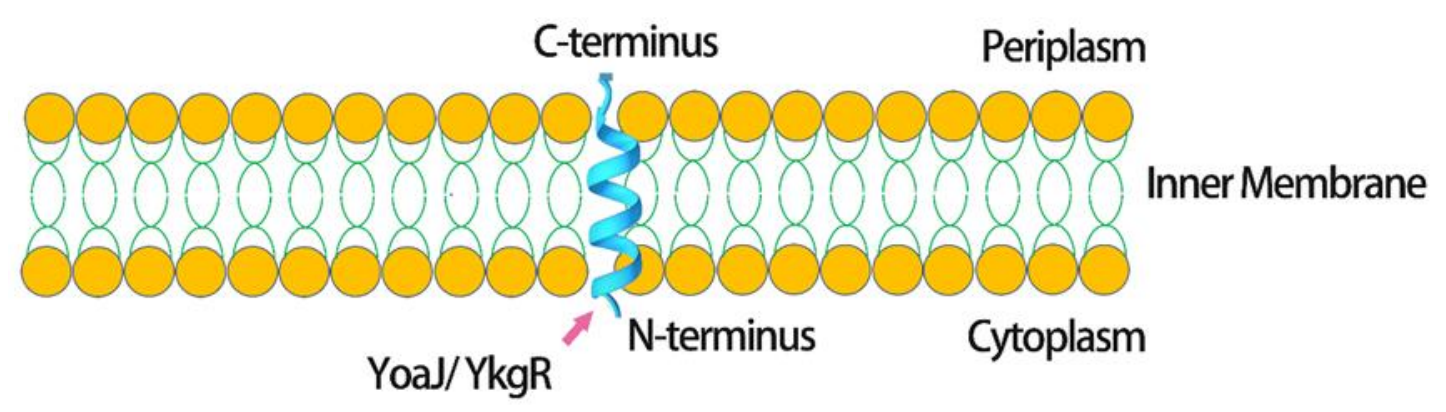

Figure 3. Location of the fusion tag (YoaJ/YkgR, small peptide, or protein) and recombinant peptide in E. coli, where $\mathrm{OM}$ is the outer membrane and IM is the inner membrane.

In this study, YoaJ/YkgR was used as a fusion tag in the periplasmic space of E. coli to generate peptides rich in disulfide bonds (Table 6). The position of YoaJ in E. coli, with its N-terminal in the cytoplasm and C-terminal in the periplasm, enables the peptides of interest to be fixed in the periplasmic space. Compared to other procedures involving E. coli periplasm, the current selection of leading peptides seems to improve the secretion efficiency and stability for the production of disulfide bridge-rich peptides and has been used to produce small peptides with favorable yields (Table 7) [123].

Table 6. Peptides used in the current study.

\begin{tabular}{cc}
\hline Peptide & Disulfide Number \\
\hline Beta-defensin & 3 \\
hepcidin & $3 / 4$ \\
DkTx & 6 \\
ASPA & 3 \\
\hline
\end{tabular}

Table 7. Comparison of yields of proteins tagged with different signal peptides produced in the periplasm of E. coli.

\begin{tabular}{ccccc}
\hline Fusion Protein & Yield $\mathbf{( m g} / \mathbf{L})$ & Disulfide Bond Number & Tag Size (kDa) & Ref \\
\hline YkgR-BD & $\sim 25$ & 3 & 4 & {$[123]$} \\
YkgR-Hep & $\sim 17$ & 4 & 4 & {$[123]$} \\
YkgR-DkTx & $\sim 8$ & 6 & 4 & {$[123]$} \\
YoaJ-ASPA & $\sim 5$ & 3 & 2.69 & {$[123]$} \\
YoaJ-BD & $\sim 10$ & 3 & 2.69 & {$[123]$} \\
DsbA-scFv & 0.3 & & 23.5 & {$[124]$} \\
MBP-nanobodies & 2.2 & & 42 & {$[125]$} \\
DsbC-Huwentoxin & 0.7 & & 23.5 & {$[126]$} \\
pelB-human growth hormone & 1.4 & 2.31 & {$[127]$} \\
\hline
\end{tabular}

\section{Co-Expression of Chaperones}

Co-expression of molecular chaperones may be advantageous for increasing the solubility and folding of proteins. While chaperone co-expression increases the development of many monomeric and multimeric proteins, the effectiveness of this strategy seems to be protein specific $[111,128,129]$. Various factors lead to the failure of overexpressed proteins to fold into their original form, including the presence of molecular chaperones, lack of disulfide links, and/or post-translational modifications. Reducing cytoplasm deactivates disulfide bond formation [130]. In E. coli, the following two mechanisms lead to the breakdown of disulfide bonds: Thioredoxin mechanism involving trxB and the glutaredoxin network containing glutathione reductase, glutathione, and three glutaredoxins [131,132]. The use of $E$. coli strains that are deficient involves techniques to generate a less reductive cytoplasmic environment that promotes the formation of disulfide bonds with trxB, which contributes to sulfhydryl reduction [111,133,134]. Finally, purifying target proteins from the cytoplasmic protein pool is a relatively challenging task, as this compartment comprises the vast majority of the total cell protein. 
The periplasm offers simple and cost-effective target protein purification from a slightly reduced pool of bacterial proteins compared to the cytoplasm. In addition, the oxidizing atmosphere of the periplasm promotes proper protein folding, and the in vivo cleavage of the signal peptide during translocation to the periplasm is more likely to deliver the authentic N-terminal of the target protein [135]. Signal peptides of prokaryotic and eukaryotic origin have been widely used for this function, although the existence of a signal peptide does not necessarily guarantee effective protein translocation across the inner membrane as certain other structural features are involved in conveying the membrane. Several techniques have been documented for improving the translocation of proteins to the periplasm, including the overproduction of the peptidase signal [136,137], reduction of protein expression levels to avoid overloading of the translocation mechanism, and co-production of several proteins involved in the membrane transport processes.

Protein folding in the periplasm can be induced by the overexpression of two types of enzymes: Protein disulfide isomerases (PDIs), which are predominantly observed in the periplasm and catalyze disulfide bond oxidation, and peptidyl-prolyl-cis-trans isomerases (PPIs), which catalyze X-pro bond isomerization [138]. At low temperatures, co-overexpression of DsbA and the heat-shock element improves the yield of correctly folded T-cell-receptor (TCR) fragments. Similarly, the coexpression of eukaryotic PDIs improves the yield of correctly folded pectate lyase $C$ and bovine pancreatic trypsin inhibitor [121].

Co-overexpression of molecular chaperones is a potential method for avoiding the development of inclusion bodies. This technique is appealing; however, there is no certainty that chaperones can increase the solubility of recombinant proteins [22,139]. E. coli encode chaperones, some of which drive the process of protein folding, while others inhibit protein aggregation [134]. As soon as freshly synthesized proteins detach from the exit site of the E. coli ribosome, they are connected with chaperone with the cause factor $[140,141]$. Exposed hydrophobic patches on freshly synthesized proteins are shielded from unwanted inter- or intramolecular interactions by associating with the trigger factor, thereby preventing premature folding. After being released from the trigger factor, proteins may start or begin to fold into their native state [142]. Proteins in non-native conformations are vulnerable to aggregation and are used as substrates for DnaK and GroEL. By inducing aggregation and encouraging the proteolysis of misfolded proteins, DnaK (Hsp70 chaperone family) inhibits the development of inclusion bodies. The solubilization or disaggregation of proteins is regulated by a bi-chaperone mechanism involving DnaK and ClpB (Hsp100 chaperone family). GroEL (Hsp60 chaperone family) regulates the movement of proteins between soluble and insoluble protein fractions and is strongly involved in the development of inclusion bodies and disaggregation. Small heat shock proteins, such as $\mathrm{lbpA}$ and $\mathrm{lbpB}$, protect heat-denatured proteins from irreversible aggregation and their expression is known to be correlated with that of inclusion bodies. The general outline is summarized in Figure 4.

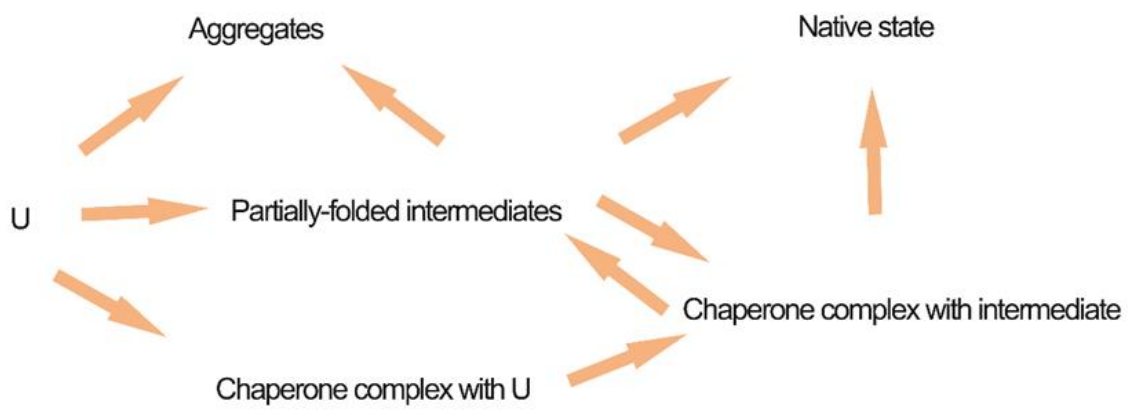

Figure 4. General outline of chaperone-mediated protein folding in a cell. U represents nascent polypeptide or newly synthesized protein. Chaperones include 40-, 60-, and 70-kDa heat shock proteins, protein disulfide isomerase, and peptidyl prolyl isomerase or trigger factor.

In many instances, simultaneous overexpression of chaperone-encoding genes and recombinant target proteins has proven to be successful. Co-overexpression of the stimulus factor in recombinants 
has inhibited the aggregation of mouse endostatin, human oxygen-regulated protein ORP150, human lysozyme, and guinea pig liver transglutaminase. Soluble expression is further enhanced along with the expression of the stimulus factor by the co-overexpression of the chaperone structures, namely, GroEL-GroES and DnaK-DnaJ-GrpE. The chaperone schemes are cooperative. The most desirable techniques include the co-expression of combinations of chaperones belonging to the chaperone families GroEL, DnaK, and ClpB, and the trigger factor aligned with the ribosome.

\section{Soluble and Insoluble Expression}

Numerous specific host strains have been developed to address the metabolic pressure associated with the high rates of protein production. The E. coli mutant strains added value to the soluble production of complicated recombinant proteins. C41(DE3) and C43(DE3) are mutants that enable the overexpression of certain globular and membrane proteins that cannot be expressed at high levels in the BL21(DE3) parent strain. The amount of cysteines present in E. coli cytoplasm is decreased by the trxB and glutaredoxin pathways. In Origami strains from Novagen, the disulfide bond-dependent folding of heterologous proteins is strengthened. Disruption of the $\operatorname{tr} x B$ and gor genes encoding the two reductases allows disulfide bonds to be established in the E. coli cytoplasm. The E. coli strains negative for $\operatorname{tr} x B$ (Novagen AD494) and $t r x B / g o r$ (Novagen Origami) have been used for protein expression. The development of folding and disulfide bonds in the target protein is facilitated by thioredoxin fusion in thioredoxin-free (trxB) strains [28]. Overexpression of periplasmic foldase DsbC in the cytoplasm further promotes the formation of disulfide bonds. Batch culture is the easiest method for the development of recombinant proteins. In this method, all nutrients required for growth are supplied from the start, and only limited control can be exercised on the production during the cycle. Sometimes, this restriction contributes to the modifications in the growth medium, such as an increase in the $\mathrm{pH}$ and the concentration of dissolved oxygen as well as the degradation of substrates. Additionally, inhibitory compounds are derived from different metabolic pathways. The cell densities and output rates in batch cultivations are moderate. The concentration of energy sources that are modified is based on the rate of consumption in the fed-batch cultivations. Many other variables may also manage to achieve the optimum amount of output per biomass with respect to the target protein $[5,135]$. In fed-batch cultivations, the development of inclusion bodies may be observed by tracking shifts in intrinsic light dispersion via cytometric flow [143]. This enables the growth conditions to be controlled in real time as soon as inclusion bodies are observed even at low rates, and the formation of such bodies may be prevented theoretically [144]. Protein folding involves the presence of a particular cofactor. The addition of such cofactors or binding partners to the culture media may significantly increase the yield of the soluble protein. This phenomenon was demonstrated with a recombinant hemoglobin mutant, resulting in an increased aggregation of the soluble substance upon excessive addition of heme factor [145]. Similarly, a 50\% improvement in the solubility of gloshedobin was observed when developed in the E. coli recombinant system with $0.1 \mathrm{mM} \mathrm{Mg}^{2+}$ [146]. The medium structure and optimization are essential considerations for the soluble expression of recombinant proteins. While this is achieved primarily by trial and error, it can be useful, nonetheless.

The overexpression of recombinant proteins in E. coli is commonly employed for manufacturing proteins in significant amounts owing to advantages, such as the development using cheap sources of energy, rapid deposition of biomass, suitability for fermentation with high cell density, and fairly quick output [14]. However, according to the data published by the Center for Eukaryotic Structure Genomics (CESG) (http:/targetdb.pdb.org/statistics/sites/CESG.html), only approximately $30 \%$ of the cloned targets in E. coli, among the total of 8048 targets, were presented in a soluble form, while the rest were presented either in a deteriorated form or as insoluble aggregates, classified as inclusion bodies [147]. While inclusion bodies cannot be used specifically for experiments involving protein activity, their insolubility offers a simple source of fairly pure protein, provided only certain proteins can be transformed to their natural and active conformation. 
To extract soluble active proteins from inclusion bodies, the insoluble inclusion bodies must be first solubilized in denaturants (Figure 5) and subsequently accompanied by a cycle of refolding (herein, referred to as the "one-step denaturing and refolding" procedure for comparison) [148]. This technique has been used for more than 20 years and is highly suitable for many bodily proteins, with approximately $40 \%$ being replenished into soluble and biologically active forms [138,149]. In this process, the inclusion bodies are denatured with a denaturing buffer containing either $6 \mathrm{M}$ guanidine hydrochloride (GdnHCl), $8 \mathrm{M}$ urea, or $0.3 \%$ sarkosyl (n-lauroyl sacosinate) [150]. However, in most situations, a substantial amount of precipitation occurs during the refolding of the proteins, resulting in a major reduction in the total yield of the desired proteins.

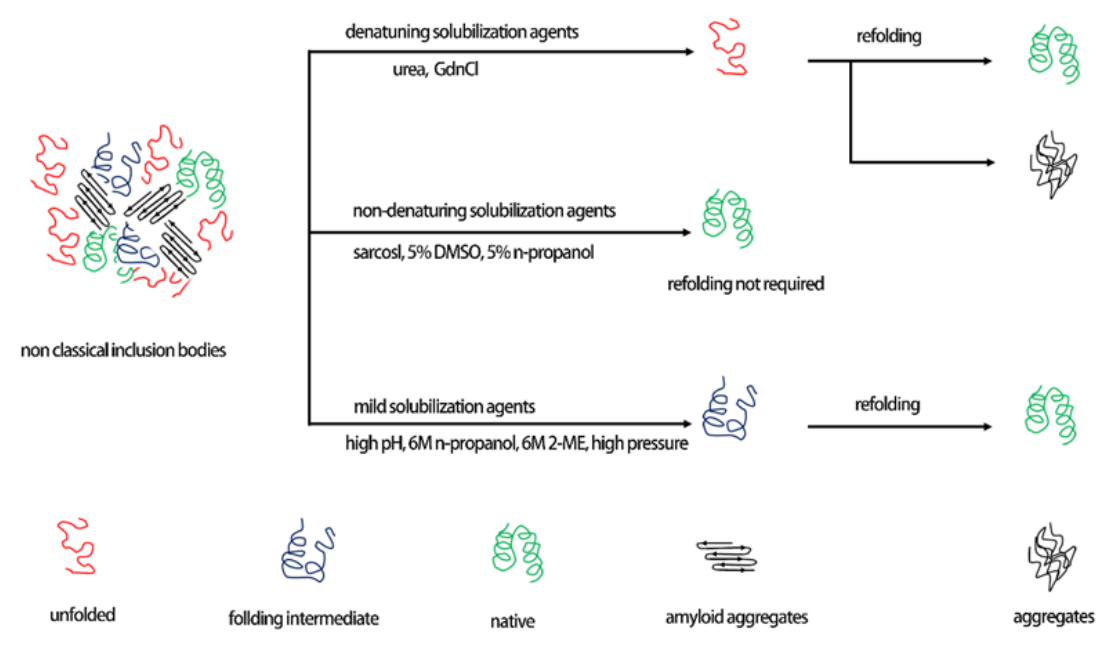

Figure 5. Model showing different solubilization methods used for the recovery of proteins from inclusion bodies.

\section{Purification}

As a chromatographic technique, IMAC offers the advantages of providing favorable and precise attachment, mild elution conditions, and the potential to monitor the selectivity by using low imidazole concentrations in chromatographic buffers [45]. The general purification process is simply illustrated in Figure 6. Those recombinant protein fused with tag can be purified by specific support resin in a column. For example, the construct of His6-insulin can be selectively purified by the Ni-NTA Agrose resin column. A broad variety of popular resins with different binding modes and abilities are available. However, all resins require difficult cleaning procedures. High-performance liquid chromatography can combine most purification steps; the most commonly utilized instruments are the ÄKTA systems from GE Healthcare [19]. The final quality of the protein can be controlled by monitoring the proportion of the recombinant protein with respect to the scale of the column; pollutants with lower affinity can interact with a greater abundance of the recombinant protein labeled with histidine. It is also useful to evaluate the sum of the soluble target protein to be loaded onto the board, which can be inferred from small-scale expression studies [151]. As a general rule, to optimize purity, the column is loaded with a small excess of the amount required to achieve the expected binding capability. While not mandatory, the implementation of such protein purification protocols with automated chromatography systems is reasonably straightforward, which has proven to be reliable, successful, and easy to use [21,152]. Protein and peptide affinity tags are widely used for the purification of recombinant proteins and native protein complexes. First, they offer 100- to 1000-fold purification of crude extracts without the need for undertaking any previous measures to eliminate nucleic acid or other cellular materials [153]. Secondly, the mild elution conditions allow the use of affinity tags valuable for purifying individual proteins, particularly complex proteins. Lastly, affinity tags permit the purification of diverse proteins using generic protocols as opposed to highly specialized procedures associated with traditional chromatography, compelling consideration for proteomics or structural genomics [1,154]. Most of 
the proteins and peptide affinity tags available have been produced during the last 20 years and can be divided into three groups based on the type of the affinity tag and its target: The first class includes epitope affinity tags used for peptide or protein fusion to tiny molecular ligands linked with a strong connection [155]. The hexa-histidine tag, for example, binds to an immobilized metal, while glutathione S-transferase protein fusions bind to glutathione that is bound to chromatographic resin [156]. The second class of affinity tags includes peptide tags that attach to an immobilized protein-binding partner on the chromatographic resin. For example, the calmodulin-binding peptide binds specifically to calmodulin, which allows the purification of proteins fused to the peptide that is attached to the calmodulin resin. The third type of epitope affinity tags may be classified in the second category, in which the protein-binding partner bound to the resin is an antibody that identifies a specific epitope of the peptide. Examples include the FLAG peptide for which an anti-FLAG antibody resin can be used. Such an abundant range of affinity tags for protein purification will render it challenging for a specific project to agree on the most suitable tag. While several, if not most, recombinant proteins are now processed and purified using affinity tags, just two to three tags have been compared in the few experiments testing affinity tags for protein purification. Thus, affinity tags are usually chosen depending on qualitative knowledge. To resolve this absence of a standardized analysis for affinity tags, we have previously measured the quality, yield, and expense by using two protein fusion and six short peptide affinity tags to purify two E. coli-expressed proteins [50]. We evaluated the capacity of the affinity resins to purify labeled proteins from extracts derived from yeast, Drosophila, and HeLa cells. Our tests, which demonstrate that the affinity tags are markedly different with respect to the efficacy of purification, offer a more robust foundation for choosing affinity tags. Several proteins and peptide affinity tags are now accessible that help distinguish proteins, which are expressed in a heterologous host, such as E. coli, or the purification by a labeled subunit of native complexes. In general, an ideal affinity tag exhibits the following properties and functions: (i) Enables the efficient purification of high-yield labeled proteins, (ii) can be used for any protein without disrupting its functions, (iii) can be positioned at any location in the protein ( $\mathrm{N}$-terminal, center, and C-terminal), (iv) can be used to purify protein produced in all host strains or expression methods, (v) can be used for the identification of recombinant proteins, and (vi) has resin attachments and elutes that are cheap, can be regenerated, and have strong flow properties. Notably, many affinity tags are available commercially that meet several, if not many, of those requirements. We analyzed two proteins and six peptide affinity tags, which met all of the above criteria, to purify recombinant proteins expressed in E. coli for their effectiveness [157]. We studied a subset of the capacity of such tags to purify proteins from three samples of eukaryotic cells. Our results report different purities of the derived proteins. We noted that epitope peptide tags, such as the FLAG peptide, yield the maximum-quality protein in E. coli, both for well-behaved and un-behaved polypeptides. Compounds derived from the bacteria, yeast, Drosophila, and HeLa include tags, such as the TAP tag involving the CBP peptide, which is widely used for the isolation of "normal" protein complexes, and the commonly used HIS tag that generates proteins with several contaminants. The Strep II (STR) tag was remarkably successful, delivering protein reliably and nearly as pure as epitope-based systems. By the purification of the affinity tag, we obtained fair yields of relatively high-purity DHFR. The truncated yeast polypeptide Gcn 5 was extracted with a relatively weak purity and in small or virtually no quantity. Thus, while the purification by affinity tags allows for the use of general purification protocols that do not rely on the quality of the protein being purified, unfavorable properties of proteins, such as aggregation, can still affect affinity tag purification experiments [118,158]. Notably, the solubility of a recombinant protein is a minimum prerequisite for correctly folded nonmembrane proteins [159]. Soluble extracts that contain tiny aggregates of the labeled protein are not pelleted when centrifuged. Although these non-specific aggregates mask the affinity tag, as observed with the labeled Gcn5 polypeptides, resulting in the labeled protein being soluble and yet unable to attach to the affinity resin. Cost may be a critical parameter, in addition to purity and yield, when selecting affinity tags and resins, particularly for preparatory purification. We measured the cost of purifying $10 \mathrm{mg}$ of a 30-kDa polypeptide using retail 
cost and resin efficiency details given by the distributors, to evaluate the price of different affinity resins. The columns MBP, Talon, Ni-NTA, and GST were the least costly, with resins costing \$12-36 to purify the labeled polypeptide by $10 \mathrm{mg}$. To purify $10 \mathrm{mg}$ of marked polypeptide, calmodulin (for CBP tag) and Strep-Tactin (for Strep II tag) were notably costlier at \$114-293. The FLAG and HPC monoclonal resins are especially costly at $\$ 1000-5000$ for the same volume of marked polypeptide due to their large unit resin cost and relatively small capacity $(0.6 \mathrm{mg}$ FLAG marked protein/mL resin versus $5-10 \mathrm{mg}$ HIS tagged protein/mL resin) [115,160-162]. Choosing an attraction suffix specifically depends upon the criteria of the experiment. Experiments requiring large amounts of partly distilled content at a low cost might consider the HIS and GST tags, while experiments requiring small quantities with the maximum purity might consider the FLAG and HPC tags to overshadow their costs and minimal ability $[107,163]$. The Strep II tag appears to be an excellent candidate for affinity purification in general, as it is a short tag that produces high-purity proteins at a moderate cost with reasonable yields. One drawback attached to the use of the Strep II tag for protein crystallization in purifying proteins is that it interferes with the crystallization of a specific enzyme. This interference is not observed with the HIS or FLAG tags. Given that certain proteins have been successfully crystallized with the Strep II tag, it is not clear whether this tag adversely affects protein crystallization. These findings highlight the need for further comprehensive research examining the influence of protein crystallization by affinity tags. We consider that a mixture of HIS and Strep II tags enables rapid capturing of the tagged protein or protein complex from rough extracts by the Talon column, accompanied by polishing over the Strep-Tactin column. To promote the usage of the tags analyzed in this review, we prepared a suite of expression vectors that include the tags HIS, CBP, STR, FLAG, HPC, and CYD as single or double cleavable and non-cleavable tags for the production of individual polypeptides and polycistronic production of protein complexes in E. coli. We hope that our comprehensive study of affinity tags can help us make better choices for the purification of proteins. Comparing different tags utilizing a similar target protein has important benefits, and we recommend testing the potential affinity tags using DHFR in the future to enable clear comparisons with current tags. The knowledge presented in this study can also help to create new, smaller tandem affinity purification (TAP) tags as alternatives to the common combination of A-CBP proteins. X-ray crystallography of integral membrane proteins is difficult, as it needs significant expenditure of time and energy to locate a membrane protein that will produce diffraction-quality crystals. Nonetheless, we have shown that unproductive large-scale protein expression and purification can be reduced by the fluorescence-detection size-exclusion chromatography (FSEC), a fast pre-crystallization screening process in which mono-dispersion and goal protein stability are defined with only nanograms of unpurified protein. In this step, the target protein is fused covalently to GFP, and SEC analyzes the resulting unpurified fusion protein. While the GFP fusion technique was previously used to track the production of bacterial membrane proteins and screen detergents used for solubilization, our understanding of the use of the covalent GFP fusion and SEC techniques to examine mono-dispersiveness and fusion protein stability for protein crystallization is novel. In addition, pre-crystallization screening based on FSEC can be used with the previously mentioned GFP fusion method to develop cell lines with high levels of expression of promising constructs. In this review, the advantages and importance of covalent GFP fusion proteins and FSEC pre-crystallization screening with eukaryotic and prokaryotic membrane proteins have been illustrated. In such tests, small quantities of unpurified target membrane proteins were tested rapidly and easily for the extent of the position and expression, degree of mono-dispersity, average molecular mass, and detergent stability. In this analysis, size exclusion chromatography (SEC) was used instead of gel permeation, gel filtration, steric exclusion, exclusion, or gel chromatography. SEC is an entropically regulated separation strategy that relies on the relative size of a macromolecule or the hydrodynamic volume over the average pore size of the packaging. Importantly, SEC is a relative technique that involves column calibration to evaluate statistical average molecular weights and the distribution of polymers by molecular weight [101]. Absolute molecular weight measurements are therefore feasible with either an electronic light scattering device or a widely controlled on-line 
viscometer. The molecular conformation of these detectors and long-chain branching may also be evaluated by these methods. Along with the ability to examine molecular parameters, SEC is often useful for the preparatory fractionation of polymers and the isolation of small molecules from large polymeric or biogenic matrices during sample cleaning [164,165]. SEC is a standard and well-accepted methodology by which organic polymers and biopolymers are characterized. We have observed a higher usage of high-performance columns than traditional soft-gel packaging in life sciences. Owing to their speed and high resolution, high-performance columns are still preferred. Both silicaand organic-based packaging are used for aqueous SEC. Silica-based packaging tends to be favored for quality management and monitoring due to better performance (smaller particle size), shorter testing period, and more durable nature than organic-based packaging. Nevertheless, unintended contact during the labeling of solvents is a huge concern. Polystyrene gels are the choice of packaging for organo-soluble polymers. In this analysis phase, less attention is given to the theoretical aspects of SEC, including band extension, and the implementations are more heavily focused on the usage of electronic light-scattering detectors and viscometers. With these molecular weight-sensitive detectors, branching, molecular scale, and conformation can now be evaluated as a feature of molecular weight in one continuous experiment. Together with a concentration-sensitive detector, the usage of any such detector has significantly increased the sensitivity and precision of these tests.

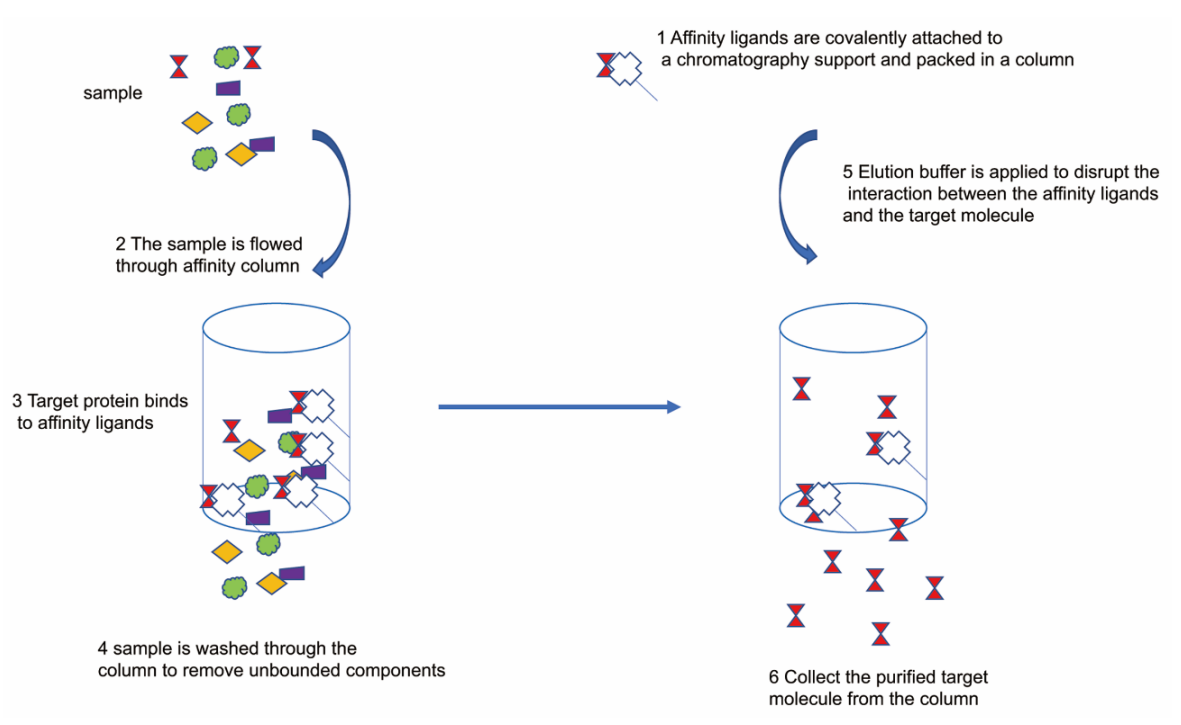

Figure 6. General protein purification process: protein of interest binds to column with resin, remove unbonded protein, and collect the target purified protein from the column by elution buffer.

\section{Conclusions}

Proteins greater than $100 \mathrm{kDa}$ are typically expressed in a eukaryotic system, while those less than $30 \mathrm{kDa}$ are expressed in a prokaryotic system [166]. Mammalian cells, bacteria, or the baculovirus systems are selected for proteins involving glycosylation. The least expensive, easiest, and quickest protein expression can be performed in E. coli. The bacterium, however, cannot produce large proteins [167]. Additionally, for S-S-rich proteins and proteins involving post-translation modifications, E. coli is not the method of choice, as it cannot perform glycosylation and eliminate the S-S fragments. Eukaryotic proteins may also be toxic to the bacteria. Proteins with disulfide bonds are typically stored in the periplasm since the cytoplasm is very limited. The periplasm offers the advantages of simplicity and cost effectiveness for target protein purification from a slightly reduced pool of bacterial proteins as opposed to the cytoplasm. Furthermore, the oxidizing environment of the periplasm promotes adequate protein folding. Hence, the in vivo cleavage of the warning peptide in the periplasm during translocation is more likely to produce the authentic N-terminal of the protein. To this end, signal peptides of prokaryotic and eukaryotic origins have been successfully 
used. The two most utilized yeasts are S. cerevisiae and P. pastoris. For a low expense, yeasts can generate high protein yields as well as proteins greater than $50 \mathrm{kDa}$ along with the extraction of signal sequences and glycosylation. Yeasts develop chaperonins to help fold those proteins and can process S-S-rich proteins [168]. The baculovirus system is a more advanced eukaryotic system than yeast, which can perform more complicated post-translational protein modifications. The most common system used to generate recombinant glycosylated mammalian proteins is the one developed using mammalian cells. Such cells can produce proteins greater than $50 \mathrm{kDa}$, accurately remove the signal chain, glycosylate, and even exhibit chaperonins. Such proteins observed in mammalian structures include factor VII, factor IX, factor IX, interleukin 2, human growth hormone, and TPA [169,170]. Transgenic animals can produce several valuable biopharmaceuticals, such as vaccines, antibodies, and other biotherapeutics [171,172]. Advances in molecular biology have been the primary guiding factor in the biopharmaceutical production of such substances and the development of high levels of protein.

In conclusion, significant progress has been observed in many technical aspects of gene expression in E. coli and yeast. The advantages of prokaryotes and eukaryotes have ensured that they remain a valuable tool for the production of recombinant proteins for both basic research and commercial applications.

Author Contributions: Y.M. and J.-S.P. conceived and designed the study. Y.M. and C.-J.L. performed the experiments. Y.M. and J.-S.P. wrote the paper. Y.M. and J.-S.P. reviewed and edited the manuscript. All authors have read and agreed to the published version of the manuscript.

Funding: This research was funded by the grant from the Marine Biotechnology Program (Grant No. 20170305; Development of Biomedical materials based on marine proteins).

Acknowledgments: This research was funded by the grant from the Marine Biotechnology Program (Grant No. 20170305; Development of Biomedical materials based on marine proteins) by the Korean Institute of Marine Science \& Technology promotion.

Conflicts of Interest: The authors declare no conflict of interest.

\section{References}

1. Basagoudanavar, S.H.; Hosamani, M.; Muthuchelvan, D.; Singh, R.P.; Santhamani, R.; Sreenivasa, B.P.; Saravanan, P.; Pandey, A.B.; Singh, R.K.; Venkataramanan, R. Baculovirus expression and purification of peste-des-petits-ruminants virus nucleocapsid protein and its application in diagnostic assay. Biol. J. Int. Assoc. Biol. Stand. 2018, 55, 38-42. [CrossRef] [PubMed]

2. Faramarzi, T.; Mobasheri, M.; Yoosefy, A.; Valadkhani, Z. Expression and purification of truncated recombinant b8/1 protein of echinococcus granulosus for diagnosis of hydatid infection in human. Acta Trop. 2019, 191, 139-145. [CrossRef] [PubMed]

3. Huang, H.; Wang, Z.; Yang, Z.; Li, Z.; Wang, P.; Dong, W. Eukaryotic expression, purification of human igecepsilon2-4 protein and its target fishing. Xi Bao Yu Fen Zi Mian Yi Xue Za Zhi Chin. J. Cell. Mol. Immunol. 2018, 34, 205-210.

4. Jeong, I.S.; Lee, S.; Bonkhofer, F.; Tolley, J.; Fukudome, A.; Nagashima, Y.; May, K.; Rips, S.; Lee, S.Y.; Gallois, P.; et al. Purification and characterization of arabidopsis thaliana oligosaccharyltransferase complexes from the native host: A protein super-expression system for structural studies. Plant J. Cell Mol. Biol. 2018, 94, 131-145. [CrossRef]

5. Mahesh, G.; Jaiswal, P.; Dey, S.; Sengupta, J.; Mukherjee, S. Cloning, expression, purification and characterization of oligomeric states of the native 5ht2a g-protein-coupled receptor. Protein Pept. Lett. 2018, 25, 390-397. [CrossRef] [PubMed]

6. $\quad \mathrm{Ng}$, E.Y.; Loh, Y.R.; Li, Y.; Li, Q.; Kang, C. Expression, purification of zika virus membrane protein-ns2b in detergent micelles for nmr studies. Protein Expr. Purif. 2019, 154, 1-6. [CrossRef]

7. Richardson, D.; Itkonen, J.; Nievas, J.; Urtti, A.; Casteleijn, M.G. Accelerated pharmaceutical protein development with integrated cell free expression, purification, and bioconjugation. Sci. Rep. 2018, 8, 11967. [CrossRef]

8. Ortega, C.; Prieto, D.; Abreu, C.; Oppezzo, P.; Correa, A. Multi-compartment and multi-host vector suite for recombinant protein expression and purification. Front. Microbiol. 2018, 9, 1384. [CrossRef] 
9. Lu, J.; Liang, W.; Wei, K.; Li, J.; Li, J.; Wang, J.; Gao, W. Induction of signal molecules and expression of functional genes after pichia pastoris stimulation in glycyrrhiza uralensis fisch adventitious roots. J. Food Biochem. 2019, 43, e12798. [CrossRef] [PubMed]

10. Lopes, C.; Dos Santos, N.V.; Dupont, J.; Pedrolli, D.B.; Valentini, S.R.; de Carvalho Santos-Ebinuma, V.; Pereira, J.F.B. Improving the cost effectiveness of enhanced green fluorescent protein production using recombinant escherichia coli bl21 (de3): Decreasing the expression inducer concentration. Biotechnol. Appl. Biochem. 2019, 66, 527-536. [CrossRef]

11. Olson, L.J.; Dahms, N.M. Cloning, expression, and purification of the glycosylated transmembrane protein, cation-dependent mannose 6-phosphate receptor, from sf9 cells using the baculovirus system. Methods Mol. Biol. 2018, 1722, 105-116. [PubMed]

12. Ramos-Benitez, M.J.; Lopez-Cruz, L.M.; Aguayo, V.; Ruiz-Jimenez, C.; Espino, A.M. Cell-free expression, purification and immunoreactivity assessment of recombinant fasciola hepatica saposin-like protein-2. Mol. Biol. Rep. 2018, 45, 1551-1556. [CrossRef] [PubMed]

13. Rajput, V.B.; Karthikeyan, M.; Ramasamy, S. Zebrafish acid ceramidase: Expression in pichia pastoris gs115and biochemical characterization. Int. J. Biol. Macromol. 2019, 122, 587-593. [CrossRef] [PubMed]

14. Shi, Y.; Halperin, S.A.; Lee, S.F. Expression, purification, and functional analysis of an antigen-targeting fusion protein composed of cd40 ligand and the c-terminal fragment of ovalbumin. Protein Expr. Purif. 2018, 142, 37-44. [CrossRef]

15. Parra, N.C.; Mansilla, R.; Aedo, G.; Vispo, N.S.; Gonzalez-Horta, E.E.; Gonzalez-Chavarria, I.; Castillo, C.; Camacho, F.; Sanchez, O. Expression and characterization of human vascular endothelial growth factor produced in siha cells transduced with adenoviral vector. Protein J. 2019, 38, 693-703. [CrossRef]

16. Subramanyam, S.; Spies, M. Expression, purification, and biochemical evaluation of human rad51 protein. Methods Enzymol. 2018, 600, 157-178.

17. Sui, Y.; Fu, X.; Wang, Y.; Hu, W.; Zhang, T.; Liu, W.; Jiang, L.; Xing, S.; Fu, X.; Xu, X. Expression, purification and characterization of a catalytic domain of human protein tyrosine phosphatase non-receptor 12 (ptpn12) in escherichia coli with fkbp-type ppiase as a chaperon. Protein Expr. Purif. 2018, 142, 45-52. [CrossRef]

18. Ouephanit, C.; Boonvitthya, N.; Bozonnet, S.; Chulalaksananukul, W. High-level heterologous expression of endo-1,4-beta-xylanase from penicillium citrinum in pichia pastoris $\mathrm{x}$-33 directed through codon optimization and optimized expression. Molecules 2019, 24, 3515. [CrossRef] [PubMed]

19. Allonso, D.; Pereira, I.B.; Alves, A.M.; Kurtenbach, E.; Mohana-Borges, R. Expression of soluble, glycosylated and correctly folded dengue virus ns1 protein in pichia pastoris. Protein Expr. Purif. 2019, 162, 9-17. [CrossRef] [PubMed]

20. Bobik, T.V.; Popov, R.Y.; Aliev, T.K.; Mokrushina, Y.A.; Shamborant, O.G.; Khurs, E.N.; Knorre, V.D.; Smirnov, I.V.; Gabibov, A.G. Production of recombinant human transferrin in eukaryotic pichia pastoris expression system. Bull. Exp. Biol. Med. 2019, 167, 335-338. [CrossRef] [PubMed]

21. Arbulu, S.; Jimenez, J.J.; Gutiez, L.; Feito, J.; Cintas, L.M.; Herranz, C.; Hernandez, P.E. Cloning and expression of synthetic genes encoding native, hybrid- and bacteriocin-derived chimeras from mature class iia bacteriocins, by pichia pastoris (syn. Komagataella spp.). Food Res. Int. 2019, 121, 888-899. [CrossRef]

22. Tagliavia, M.; Nicosia, A. Advanced strategies for food-grade protein production: A new E. Coli/lactic acid bacteria shuttle vector for improved cloning and food-grade expression. Microorganisms 2019, 7, 116. [CrossRef] [PubMed]

23. Zhou, H.H.; Zhang, A.X.; Zhang, Y.; Zhu, D.Y. Cloning, expression, and purification of a recombinant tat-ha-nr2b9c peptide. Protein Expr. Purif. 2012, 85, 239-245. [CrossRef] [PubMed]

24. Zheng, X.; Dong, S.; Zheng, J.; Li, D.; Li, F.; Luo, Z. Expression, stabilization and purification of membrane proteins via diverse protein synthesis systems and detergents involving cell-free associated with self-assembly peptide surfactants. Biotechnol. Adv. 2014, 32, 564-574. [CrossRef] [PubMed]

25. Zorko, M.; Japelj, B.; Hafner-Bratkovic, I.; Jerala, R. Expression, purification and structural studies of a short antimicrobial peptide. Biochim. Biophys. Acta 2009, 1788, 314-323. [CrossRef]

26. Zhu, B.; Pu, Q.; Chen, N.; Chen, S. Expression, purification, and bone-inducing activity of recombinant human bone morphogenetic protein-3 mature peptide. Chin. J. Biotechnol. 1999, 15, 153-158.

27. Zhou, L.; Lin, Q.; Li, B.; Li, N.; Zhang, S. Expression and purification the antimicrobial peptide $\mathrm{cm} 4$ in escherichia coli. Biotechnol. Lett. 2009, 31, 437-441. [CrossRef] 
28. Zheng, P.; Gao, F.; Deng, K.; Gong, W.; Sun, Z. Expression, purification and preliminary x-ray crystallographic analysis of arf1-gdp in complex with dimeric p23 peptide. Acta Crystallogr. Sect. F Struct. Biol. Cryst. Commun. 2013, 69, 1155-1158. [CrossRef]

29. Zheng, H.L.; Li, H.; Sun, Y.S.; Yang, Z.Y.; Yu, Q. Parathyroid hormone-related peptide (pthrp): Prokaryotic expression, purification, and preparation of a polyclonal antibody. Genet. Mol. Res. GMR 2014, 13, 6448-6454. [CrossRef]

30. Zheng, C.F.; Simcox, T.; Xu, L.; Vaillancourt, P. A new expression vector for high level protein production, one step purification and direct isotopic labeling of calmodulin-binding peptide fusion proteins. Gene 1997, 186, 55-60. [CrossRef]

31. Zhang, Z.Z.; Yang, S.S.; Dou, H.; Mao, J.F.; Li, K.S. Expression, purification, and c-terminal amidation of recombinant human glucagon-like peptide-1. Protein Expr. Purif. 2004, 36, 292-299. [CrossRef] [PubMed]

32. Zhang, X.Y.; Zhang, J.C.; Zhao, H. Expression and purification of human amelogenin mature peptide in escherichia coli. Zhonghua Kou Qiang Yi Xue Za Zhi = Zhonghua Kouqiang Yixue Zazhi Chin. J. Stomatol. 2009, 44, 279-281.

33. Zhang, X.G.; Wang, W.N.; Zhang, C.S.; Li, K.; Ma, G.D.; Li, J.Y. Expression and purification of delta sleep-inducing peptide fused with protein transduction domain and human serum albumin in pichia pastoris. Protein Pept. Lett. 2017, 24, 668-675. [CrossRef] [PubMed]

34. Zhang, L.; Yu, H.; Song, C.; Lin, X.; Chen, B.; Tan, C.; Cao, G.; Wang, Z. Expression, purification, and characterization of recombinant human beta-amyloid42 peptide in escherichia coli. Protein Expr. Purif. 2009, 64, 55-62. [CrossRef]

35. Zhang, H.; Huang, P.F.; Meng, E.; Li, W.Y.; Zhou, L.; Zhu, L.Y.; Wu, L.; Li, M.J.; Liang, S.P.; Zhang, D.Y. An efficient strategy for heterologous expression and purification of active peptide hainantoxin-iv. PLoS ONE 2015, 10, e0117099. [CrossRef]

36. Zhang, C.; Cai, Q.; Li, Z.; Zhai, C.; Zheng, Y. Construction of fusion expression vector of human-derived neurotrophin- 6 gene encoding mature peptide and purification of its expressed product. Sheng Wu Yi Xue Gong Cheng Xue Za Zhi J. Biomed. Eng. Shengwu Yixue Gongchengxue Zazhi 2005, 22, 1241-1244.

37. Yang, K.; Su, Y.; Li, J.; Sun, J.; Yang, Y. Expression and purification of the antimicrobial peptide cecropin ad by fusion with cationic elastin-like polypeptides. Protein Expr. Purif. 2012, 85, 200-203. [CrossRef]

38. Xu, X.; Jin, F.; Yu, X.; Ji, S.; Wang, J.; Cheng, H.; Wang, C.; Zhang, W. Expression and purification of a recombinant antibacterial peptide, cecropin, from escherichia coli. Protein Expr. Purif. 2007, 53, $293-301$. [CrossRef]

39. Xu, J.; Zhu, Z.; Duan, P.; Li, W.; Zhang, Y.; Wu, J.; Hu, Z.; Roque, R.S.; Liu, J. Cloning, expression, and purification of a highly immunogenic recombinant gonadotropin-releasing hormone (gnrh) chimeric peptide. Protein Expr. Purif. 2006, 50, 163-170. [CrossRef]

40. Xu, C.S.; Tao, K.; Zheng, D.X.; Zheng, C.X.; Liu, S.L. Isolation and purification of a small peptide with activity of increasing e-receptor expression from calf thymus. Immunol. Investig. 1985, 14, 355-365.

41. Xing, L.; Xu, W.; Zhou, B.; Chen, Y.; Lin, Z. Facile expression and purification of the antimicrobial peptide histatin 1 with a cleavable self-aggregating tag (csat) in escherichia coli. Protein Expr. Purif. 2013, 88, 248-253. [CrossRef] [PubMed]

42. Xie, Y.G.; Han, F.F.; Luan, C.; Zhang, H.W.; Feng, J.; Choi, Y.J.; Groleau, D.; Wang, Y.Z. High-yield soluble expression and simple purification of the antimicrobial peptide og2 using the intein system in escherichia coli. Biomed. Res. Int. 2013, 2013, 754319. [CrossRef] [PubMed]

43. Xie, P.; Wang, Y.X.; Gao, R.K.; Zhou, L.J. Optimization of expression and purification protocol for human scfv antibody against beta-amyloid peptide. Xi Bao Yu Fen Zi Mian Yi Xue Za Zhi Chin. J. Cell. Mol. Immunol. 2012, 28, 718-721.

44. Xia, L.; Liu, Z.; Ma, J.; Sun, S.; Yang, J.; Zhang, F. Expression, purification and characterization of cecropin antibacterial peptide from bombyx mori in saccharomyces cerevisiae. Protein Expr. Purif. 2013, 90, 47-54. [CrossRef] [PubMed]

45. Ahmad, B.; Hanif, Q.; Xubiao, W.; Lulu, Z.; Shahid, M.; Dayong, S.; Rijun, Z. Expression and purification of hybrid 1l-37talpha1 peptide in pichia pastoris and evaluation of its immunomodulatory and anti-inflammatory activities by lps neutralization. Front. Immunol. 2019, 10, 1365. [CrossRef] 
46. Baeshen, M.N.; Bouback, T.A.; Alzubaidi, M.A.; Bora, R.S.; Alotaibi, M.A.; Alabbas, O.T.; Alshahrani, S.M.; Aljohani, A.A.; Munshi, R.A.; Al-Hejin, A.; et al. Expression and purification of c-peptide containing insulin using pichia pastoris expression system. Biomed Res. Int. 2016, 2016, 3423685. [CrossRef]

47. Bang, S.K.; Kang, C.S.; Han, M.D.; Bang, I.S. Expression of recombinant hybrid peptide hinnavin ii/alpha-melanocyte-stimulating hormone in escherichia coli: Purification and characterization. J. Microbiol. 2010, 48, 24-29. [CrossRef]

48. Cao, P.; Yu, J.; Lu, W.; Cai, X.; Wang, Z.; Gu, Z.; Zhang, J.; Ye, T.; Wang, M. Expression and purification of an antitumor-analgesic peptide from the venom of mesobuthus martensii karsch by small ubiquitin-related modifier fusion in escherichia coli. Biotechnol. Prog. 2010, 26, 1240-1244. [CrossRef]

49. Cao, W.; Zhou, Y.; Ma, Y.; Luo, Q.; Wei, D. Expression and purification of antimicrobial peptide adenoregulin with c-amidated terminus in escherichia coli. Protein Expr. Purif. 2005, 40, 404-410. [CrossRef]

50. Cao, Z.; Wang, W.; Xiao, X.; Chen, K.; Liang, X.; Yu, D. High-level expression and purification of an analgesic peptide from buthus martensii karch. Protein Pept. Lett. 2007, 14, 247-251. [CrossRef]

51. Rahman, M.A.; Brot, N.; Weissbach, H. High level expression and purification of peptide methionine sulfoxide reductase in escherichia coli. Cell. Mol. Biol. 1992, 38, 529-542. [PubMed]

52. Peng, H.; Yang, M.; Huang, W.S.; Ding, J.; Qu, H.D.; Cai, J.J.; Zhang, N.; Wang, K.J. Soluble expression and purification of a crab antimicrobial peptide scygonadin in different expression plasmids and analysis of its antimicrobial activity. Protein Expr. Purif. 2010, 70, 109-115. [CrossRef]

53. Pei, Z.; Sun, X.; Tang, Y.; Wang, K.; Gao, Y.; Ma, H. Cloning, expression, and purification of a new antimicrobial peptide gene from musca domestica larva. Gene 2014, 549, 41-45. [CrossRef] [PubMed]

54. Park, T.J.; Kim, J.S.; Choi, S.S.; Kim, Y. Cloning, expression, isotope labeling, purification, and characterization of bovine antimicrobial peptide, lactophoricin in escherichia coli. Protein Expr. Purif. 2009, 65, 23-29. [CrossRef] [PubMed]

55. Oh, K.S.; Na, D.K.; Kweon, M.H.; Sung, H.C. Expression and purification of the anticomplementary peptide sh-crit-ed1 (formerly sh-tor-ed1) as a tetramultimer in escherichia coli. Protein Expr. Purif. 2003, 27, $202-209$. [CrossRef]

56. Nguyen, H.Q.; Vu, V.H.; Le, P.D.; Chu, H.M. High-level expression, purification and properties of an endochitinase gene without signal peptide from lecanicillium lecanii $43 \mathrm{~h}$ in pichia pastoris. Mol. Biol. Rep. 2018, 45, 1067-1075. [CrossRef]

57. Nagata-Uchiyama, M.; Yaguchi, M.; Hirano, Y.; Ueda, T. Expression and purification of uniformly (15)n-labeled amyloid beta peptide 1-40 in escherichia coli. Protein Pept. Lett. 2007, 14, 788-792. [CrossRef]

58. Nadaud, P.S.; Sarkar, M.; Wu, B.; MacPhee, C.E.; Magliery, T.J.; Jaroniec, C.P. Expression and purification of a recombinant amyloidogenic peptide from transthyretin for solid-state nmr spectroscopy. Protein Expr. Purif. 2010, 70, 101-108. [CrossRef]

59. Mulder, K.C.; de Lima, L.A.; Aguiar, P.S.; Carneiro, F.C.; Franco, O.L.; Dias, S.C.; Parachin, N.S. Production of a modified peptide clavanin in pichia pastoris: Cloning, expression, purification and in vitro activities. AMB Express 2015, 5, 129. [CrossRef]

60. Moon, W.J.; Hwang, D.K.; Park, E.J.; Kim, Y.M.; Chae, Y.K. Recombinant expression, isotope labeling, refolding, and purification of an antimicrobial peptide, piscidin. Protein Expr. Purif. 2007, 51, 141-146. [CrossRef]

61. Mo, Q.; Fu, A.; Lin, Z.; Wang, W.; Gong, L.; Li, W. Expression and purification of antimicrobial peptide ap2 using sumo fusion partner technology in escherichia coli. Lett. Appl. Microbiol. 2018, 67, 606-613. [CrossRef]

62. Misono, K.S.; Sivasubramanian, N.; Berkner, K.; Zhang, X. Expression and purification of the extracellular ligand-binding domain of the atrial natriuretic peptide (anp) receptor: Monovalent binding with anp induces 2:2 complexes. Biochemistry 1999, 38, 516-523. [CrossRef] [PubMed]

63. Meiyalaghan, S.; Latimer, J.M.; Kralicek, A.V.; Shaw, M.L.; Lewis, J.G.; Conner, A.J.; Barrell, P.J. Expression and purification of the antimicrobial peptide gsl1 in bacteria for raising antibodies. BMC Res. Notes 2014, 7, 777. [CrossRef] [PubMed]

64. Mehrnejad, F.; Naderi-Manesh, H.; Ranjbar, B.; Maroufi, B.; Asoodeh, A.; Doustdar, F. Pcr-based gene synthesis, molecular cloning, high level expression, purification, and characterization of novel antimicrobial peptide, brevinin-2r, in escherichia coli. Appl. Biochem. Biotechnol. 2008, 149, 109-118. [CrossRef] [PubMed] 
65. Masterson, L.R.; Bortone, N.; Yu, T.; Ha, K.N.; Gaffarogullari, E.C.; Nguyen, O.; Veglia, G. Expression and purification of isotopically labeled peptide inhibitors and substrates of camp-dependant protein kinase a for nmr analysis. Protein Expr. Purif. 2009, 64, 231-236. [CrossRef] [PubMed]

66. Ma, C.; Gao, M.; Liu, W.; Zhu, J.; Tian, H.; Gao, X.; Yao, W. Intein-mediated expression and purification of an analog of glucagon-like peptide-1 in escherichia coli. Protein Pept. Lett. 2010, 17, 1245-1250. [CrossRef]

67. Wei, Q.; Kim, Y.S.; Seo, J.H.; Jang, W.S.; Lee, I.H.; Cha, H.J. Facilitation of expression and purification of an antimicrobial peptide by fusion with baculoviral polyhedrin in escherichia coli. Appl. Environ. Microbiol. 2005, 71, 5038-5043. [CrossRef]

68. Wang, Z.; Wang, W.; Shao, Z.; Gao, B.; Li, J.; Ma, J.; Li, J.; Che, H.; Zhang, W. Eukaryotic expression and purification of anti-epilepsy peptide of buthus martensii karsch and its protein interactions. Mol. Cell. Biochem. 2009, 330, 97-104. [CrossRef]

69. Wang, Y.; Wang, L.; Cui, Y.; Song, Y.B.; Liu, Y.F.; Zhang, R.; Wu, C.F.; Zhang, J.H. Purification, characterization and functional expression of a new peptide with an analgesic effect from chinese scorpion buthus martensii karsch (bmk agp-sypu1). Biomed. Chromatogr. BMC 2011, 25, 801-807. [CrossRef]

70. Wang, X.L.; Ma, S.N.; Yuan, Y.H.; Ding, Y.; Li, D.S. Expression and purification recombinant antihypertensive peptide ameliorates hypertension in rats with spontaneous hypertension. Protein Expr. Purif. 2015, 113, 30-34. [CrossRef]

71. Wang, Q.; Zhu, F.; Xin, Y.; Liu, J.; Luo, L.; Yin, Z. Expression and purification of antimicrobial peptide buforin iib in escherichia coli. Biotechnol. Lett. 2011, 33, 2121-2126. [CrossRef] [PubMed]

72. Wang, A.; Wang, S.; Shen, M.; Chen, F.; Zou, Z.; Ran, X.; Cheng, T.; Su, Y.; Wang, J. High level expression and purification of bioactive human alpha-defensin 5 mature peptide in pichia pastoris. Appl. Microbiol. Biotechnol. 2009, 84, 877-884. [CrossRef] [PubMed]

73. Wu, M.; Zhao, L.; Zhu, L.; Chen, Z.; Li, H. Expression and purification of chimeric peptide comprising egfr b-cell epitope and measles virus fusion protein t-cell epitope in escherichia coli. Protein Expr. Purif. 2013, 88, 7-12. [CrossRef] [PubMed]

74. Walsh, D.M.; Thulin, E.; Minogue, A.M.; Gustavsson, N.; Pang, E.; Teplow, D.B.; Linse, S. A facile method for expression and purification of the alzheimer's disease-associated amyloid beta-peptide. FEBS J. 2009, 276, 1266-1281. [CrossRef] [PubMed]

75. Tu, W.; Li, T.; Wang, Q.; Cai, K.; Gao, X.; Wang, H. A simple method for expression and purification of shiga toxin 1 (stx1) with biological activities by using a single-promoter vector and native signal peptide. Biotechnol. Appl. Biochem. 2016, 63, 539-545. [CrossRef] [PubMed]

76. Tran, D.Q.; Andersson, J.; Hardwick, D.; Bebris, L.; Illei, G.G.; Shevach, E.M. Selective expression of latency-associated peptide (lap) and il-1 receptor type i/ii (cd121a/cd121b) on activated human foxp3+ regulatory $t$ cells allows for their purification from expansion cultures. Blood 2009, 113, 5125-5133. [CrossRef] [PubMed]

77. Theis, S.; Doring, F.; Daniel, H. Expression of the myc/his-tagged human peptide transporter hpept1 in yeast for protein purification and functional analysis. Protein Expr. Purif. 2001, 22, 436-442. [CrossRef]

78. Tao, Y.; Zhao, D.M.; Wen, Y. Expression, purification and antibacterial activity of the channel catfish hepcidin mature peptide. Protein Expr. Purif. 2014, 94, 73-78. [CrossRef]

79. Sun, Y.L.; Liu, Y.S.; Yang, H.J.; Wang, C.S.; Ma, J.Z. Study on the expression, purification and the anti-endotoxin activity of human endotoxin binding peptide and its mutant. Zhonghua Shao Shang Za Zhi Zhonghua Shaoshang Zazhi Chin. J. Burn. 2006, 22, 291-295.

80. Wu, Y.; Ma, Y.; Li, L.; Yang, X. Molecular modification, expression and purification of new subtype antioxidant peptide from pinctada fucata by recombinant escherichia coli to improve antioxidant-activity. J. Food Sci. Technol. 2018, 55, 4266-4275. [CrossRef]

81. Sun, Y.; Li, Q.; Li, Z.; Zhang, Y.; Zhao, J.; Wang, L. Molecular cloning, expression, purification, and functional characterization of palustrin-2ce, an antimicrobial peptide of rana chensinensis. Biosci. Biotechnol. Biochem. 2012, 76, 157-162. [CrossRef]

82. Stevens, C.M.; Paetzel, M. Purification of a tat leader peptide by co-expression with its chaperone. Protein Expr. Purif. 2012, 84, 167-172. [CrossRef] [PubMed]

83. Saez, N.J.; Nozach, H.; Blemont, M.; Vincentelli, R. High throughput quantitative expression screening and purification applied to recombinant disulfide-rich venom proteins produced in e. Coli. J. Vis. Exp. JoVE 2014, 89, e51464. [CrossRef] 
84. Klint, J.K.; Senff, S.; Saez, N.J.; Seshadri, R.; Lau, H.Y.; Bende, N.S.; Undheim, E.A.; Rash, L.D.; Mobli, M.; King, G.F. Production of recombinant disulfide-rich venom peptides for structural and functional analysis via expression in the periplasm of e. Coli. PLoS ONE 2013, 8, e63865. [CrossRef] [PubMed]

85. Sha, C.; Yu, X.W.; Lin, N.X.; Zhang, M.; Xu, Y. Enhancement of lipase r27rcl production in pichia pastoris by regulating gene dosage and co-expression with chaperone protein disulfide isomerase. Enzym. Microb. Technol. 2013, 53, 438-443. [CrossRef] [PubMed]

86. Laboissiere, M.C.; Chivers, P.T.; Raines, R.T. Production of rat protein disulfide isomerase in saccharomyces cerevisiae. Protein Expr. Purif. 1995, 6, 700-706. [CrossRef] [PubMed]

87. Singh, S.K.; Tiendrebeogo, R.W.; Chourasia, B.K.; Kana, I.H.; Singh, S.; Theisen, M. Lactococcus lactis provides an efficient platform for production of disulfide-rich recombinant proteins from plasmodium falciparum. Microb. Cell Factories 2018, 17, 55. [CrossRef] [PubMed]

88. Srinivasulu, B.; Syvitski, R.; Seo, J.K.; Mattatall, N.R.; Knickle, L.C.; Douglas, S.E. Expression, purification and structural characterization of recombinant hepcidin, an antimicrobial peptide identified in japanese flounder, paralichthys olivaceus. Protein Expr. Purif. 2008, 61, 36-44. [CrossRef]

89. Solov'eva, O.V.; Kakuev, D.L.; Gibanova, N.V.; Lipkin, V.M. Deletion mutants of the natriuretic peptide receptor type b: Expression of cdna, purification and characteristics of proteins. Bioorganicheskaia Khimiia 2000, 26, 433-441. [CrossRef]

90. Shen, L.; Guo, Z.Y.; Chen, Y.; Liu, L.Y.; Feng, Y.M. Expression, purification, characterization of amphioxus insulin-like peptide and preparation of polyclonal antibody to it. Sheng Wu Hua Xue Yu Sheng Wu Wu Li Xue Bao Acta Biochim. Biophys. Sin. 2001, 33, 629-633.

91. Sharpe, S.; Yau, W.M.; Tycko, R. Expression and purification of a recombinant peptide from the alzheimer's beta-amyloid protein for solid-state nmr. Protein Expr. Purif. 2005, 42, 200-210. [CrossRef] [PubMed]

92. Sharon, M.; Gorlach, M.; Levy, R.; Hayek, Y.; Anglister, J. Expression, purification, and isotope labeling of a gp120 v3 peptide and production of a fab from a hiv-1 neutralizing antibody for nmr studies. Protein Expr. Purif. 2002, 24, 374-383. [CrossRef] [PubMed]

93. Shanmuganathan, A.; Bishop, A.C.; French, K.C.; McCallum, S.A.; Makhatadze, G.I. Bacterial expression and purification of the amyloidogenic peptide papf39 for multidimensional nmr spectroscopy. Protein Expr. Purif. 2013, 88, 196-200. [CrossRef] [PubMed]

94. Sanchez-Cach, L.A.; Ortiz-Garcia, M.M.; Minero-Garcia, Y.; Munoz-Sanchez, J.A.; Hernandez-Sotomayor, S.T.; Suarez-Solis, V.M.; De Los Santos-Briones, C. Isolation of cdna encoding the catalytic site of phosphatidylinositol-specific phospholipase c from coffea arabica 1.: Recombinant expression and peptide purification. Plant Signal. Behav. 2008, 3, 913-916. [CrossRef] [PubMed]

95. Riahi, N.; Cappadocia, L.; Henry, O.; Omichinski, J.; De Crescenzo, G. Soluble expression, purification and functional characterization of a coil peptide composed of a positively charged and hydrophobic motif. Amino Acids 2016, 48, 567-577. [CrossRef] [PubMed]

96. Rao, S.; Zang, X.; Yang, Z.; Gao, L.; Yin, Y.; Fang, W. Soluble expression and purification of the recombinant bioactive peptide precursor bpp-1 in escherichia coli using a celp-sumo dual fusion system. Protein Expr. Purif. 2016, 118, 113-119. [CrossRef]

97. Ramos, R.; Moreira, S.; Rodrigues, A.; Gama, M.; Domingues, L. Recombinant expression and purification of the antimicrobial peptide magainin-2. Biotechnol. Prog. 2013, 29, 17-22. [CrossRef]

98. Lv, Z.; Ou, Y.; Li, Q.; Zhang, W.; Ye, B.; Wu, W. Expression, purification and bioactivities analysis of recombinant active peptide from shark liver. Mar. Drugs 2009, 7, 258-267. [CrossRef]

99. Long, F.; Cho, W.; Ishii, Y. Expression and purification of 15n- and 13c-isotope labeled 40-residue human alzheimer's beta-amyloid peptide for nmr-based structural analysis. Protein Expr. Purif. 2011, 79, 16-24. [CrossRef]

100. Li, Y.; Wang, J.; Yang, J.; Wan, C.; Wang, X.; Sun, H. Recombinant expression, purification and characterization of antimicrobial peptide orbk in escherichia coli. Protein Expr. Purif. 2014, 95, 182-187. [CrossRef]

101. Li, Y.; Ren, S.; Gong, W. Cloning, high-level expression, purification and crystallization of peptide deformylase from leptospira interrogans. Acta Crystallogr. Sect. D Biol. Crystallogr. 2002, 58, 846-848. [CrossRef] [PubMed]

102. Li, Y.; Li, X.; Wang, G. Cloning, expression, isotope labeling, and purification of human antimicrobial peptide 11-37 in escherichia coli for nmr studies. Protein Expr. Purif. 2006, 47, 498-505. [CrossRef] [PubMed] 
103. Li, L.; Wang, J.X.; Zhao, X.F.; Kang, C.J.; Liu, N.; Xiang, J.H.; Li, F.H.; Sueda, S.; Kondo, H. High level expression, purification, and characterization of the shrimp antimicrobial peptide, ch-penaeidin, in pichia pastoris. Protein Expr. Purif. 2005, 39, 144-151. [CrossRef]

104. Li, J.; Zheng, L.; Li, P.; Wang, F. Intein-mediated expression, purification, and characterization of thymosin alpha1-thymopentin fusion peptide in escherichia coli. Protein Expr. Purif. 2012, 84, 1-8. [CrossRef] [PubMed]

105. Le, L.T.M.; Nyengaard, J.R.; Golas, M.M.; Sander, B. Vectors for expression of signal peptide-dependent proteins in baculovirus/insect cell systems and their application to expression and purification of the high-affinity immunoglobulin gamma fc receptor i in complex with its gamma chain. Mol. Biotechnol. 2018, 60, 31-40. [CrossRef] [PubMed]

106. Lee, T.V.; Lott, J.S.; Johnson, R.D.; Arcus, V.L. Expression and purification of an adenylation domain from a eukaryotic nonribosomal peptide synthetase: Using structural genomics tools for a challenging target. Protein Expr. Purif. 2010, 74, 162-168. [CrossRef] [PubMed]

107. Li, B.C.; Zhang, S.Q.; Dan, W.B.; Chen, Y.Q.; Cao, P. Expression in escherichia coli and purification of bioactive antibacterial peptide abp-cm4 from the chinese silk worm, bombyx mori. Biotechnol. Lett. 2007, 29, 1031-1036. [CrossRef]

108. Kumar, P.; Vahedi-Faridi, A.; Merino, E.; Lopez de Castro, J.A.; Volz, A.; Ziegler, A.; Saenger, W.; Uchanska-Ziegler, B. Expression, purification and preliminary $x$-ray crystallographic analysis of the human major histocompatibility antigen hla-b*1402 in complex with a viral peptide and with a self-peptide. Acta Crystallogr. Sect. F Struct. Biol. Cryst. Commun. 2007, 63, 631-634. [CrossRef]

109. Kuddus, M.R.; Rumi, F.; Tsutsumi, M.; Takahashi, R.; Yamano, M.; Kamiya, M.; Kikukawa, T.; Demura, M.; Aizawa, T. Expression, purification and characterization of the recombinant cysteine-rich antimicrobial peptide snakin-1 in pichia pastoris. Protein Expr. Purif. 2016, 122, 15-22. [CrossRef]

110. Wang, J.; Zhang, T.; Li, Y.; Li, L.; Wang, Y.; Yang, B.; Wang, Y. High-level expression of thermomyces dupontii thermo-alkaline lipase in pichia pastoris under the control of different promoters. 3 Biotech 2019, 9, 33. [CrossRef]

111. Verdu, C.; Sanchez, E.; Ortega, C.; Hidalgo, A.; Berenguer, J.; Mencia, M. A modular vector toolkit with a tailored set of thermosensors to regulate gene expression in thermus thermophilus. ACS Omega 2019, 4, 14626-14632. [CrossRef]

112. Velastegui, E.; Theron, C.; Berrios, J.; Fickers, P. Downregulation by organic nitrogen of aox1 promoter used for controlled expression of foreign genes in the yeast pichia pastoris. Yeast 2019, 36, 297-304. [CrossRef] [PubMed]

113. Varela, G.M.; Stroppa, M.M.; Garcia, B.A. Daily variations in the expression of genes related to insecticide resistance in the chagas disease vector triatoma infestans (hemiptera: Reduviidae). Am. J. Trop. Med. Hyg. 2019, 100, 1482-1485. [CrossRef] [PubMed]

114. Trabelsi, S.; Sahnoun, M.; Elgharbi, F.; Ameri, R.; Ben Mabrouk, S.; Mezghani, M.; Hmida-Sayari, A.; Bejar, S. Aspergillus oryzae s2 amya amylase expression in pichia pastoris: Production, purification and novel properties. Mol. Biol. Rep. 2019, 46, 921-932. [CrossRef] [PubMed]

115. Theron, C.W.; Berrios, J.; Steels, S.; Telek, S.; Lecler, R.; Rodriguez, C.; Fickers, P. Expression of recombinant enhanced green fluorescent protein provides insight into foreign gene-expression differences between mut+ and muts strains of pichia pastoris. Yeast 2019, 36, 285-296. [CrossRef]

116. Duong, T.T.; Lim, J.; Vasireddy, V.; Papp, T.; Nguyen, H.; Leo, L.; Pan, J.; Zhou, S.; Chen, H.I.; Bennett, J.; et al. Comparative aav-egfp transgene expression using vector serotypes $1-9,7 \mathrm{~m} 8$, and $8 \mathrm{~b}$ in human pluripotent stem cells, rpes, and human and rat cortical neurons. Stem Cells Int. 2019, 2019, 7281912. [CrossRef]

117. Palanikumar, I.; Katla, S.; Tahara, N.; Yui, M.; Zhang, R.; Ebihara, A.; Sivaprakasam, S. Heterologous expression, purification, and functional characterization of recombinant ovine angiotensinogen in the methylotrophic yeast pichia pastoris. Biotechnol. Prog. 2019, 35, e2866. [CrossRef]

118. Huang, L.; Peng, F.; Wei, Y.; He, W.; Zhao, S.; Wang, J.; Zhang, Y.; Zhao, H.; Deng, W. A novel method to investigate the effects of gene mutations at the cellular level using a dual expression lentiviral vector. Biosci. Rep. 2019, 39, BSR20182383. [CrossRef]

119. Jervis, A.J.; Carbonell, P.; Taylor, S.; Sung, R.; Dunstan, M.S.; Robinson, C.J.; Breitling, R.; Takano, E.; Scrutton, N.S. Selprom: A queryable and predictive expression vector selection tool for escherichia coli. ACS Synth. Biol. 2019, 8, 1478-1483. [CrossRef] 
120. Vasques, R.M.; Correa, R.F.T.; da Silva, L.A.; Blawid, R.; Nagata, T.; Ribeiro, B.M.; Ardisson-Araujo, D.M.P. Assembly of tomato blistering mosaic virus-like particles using a baculovirus expression vector system. Arch. Virol. 2019, 164, 1753-1760. [CrossRef]

121. Tran, H.H.; Chen, B.; Chen, H.; Menassa, R.; Hao, X.; Bernards, M.; Huner, N.P.A.; Wang, A. Development of a cucumber green mottle mosaic virus-based expression vector for the production in cucumber of neutralizing epitopes against a devastating animal virus. J. Virol. Methods 2019, 269, 18-25. [CrossRef] [PubMed]

122. Fontaine, F.; Fuchs, R.T.; Storz, G. Membrane localization of small proteins in escherichia coli. J Biol. Chem. 2011, 286, 32464-32474. [CrossRef] [PubMed]

123. Chang, Z.; Lu, M.; Ma, Y.; Kwag, D.G.; Kim, S.H.; Park, J.M.; Nam, B.H.; Kim, Y.O.; An, C.M.; Li, H.; et al. Production of disulfide bond-rich peptides by fusion expression using small transmembrane proteins of escherichia coli. Amino Acids 2015, 47, 579-587. [CrossRef] [PubMed]

124. Okamoto, S.; Amaishi, Y.; Goto, Y.; Ikeda, H.; Fujiwara, H.; Kuzushima, K.; Yasukawa, M.; Shiku, H.; Mineno, J. A promising vector for tcr gene therapy: Differential effect of sirna, 2a peptide, and disulfide bond on the introduced tcr expression. Mol. Ther. Nucl. Acids 2012, 1, e63. [CrossRef]

125. Nguyen, V.D.; Hatahet, F.; Salo, K.E.H.; Enlund, E.; Zhang, C.; Ruddock, L.W. Pre-expression of a sulfhydryl oxidase significantly increases the yields of eukaryotic disulfide bond containing proteins expressed in the cytoplasm of e-coli. Microb. Cell Fact. 2011, 10, 1-13. [CrossRef]

126. De Marco, A. Strategies for successful recombinant expression of disulfide bond-dependent proteins in escherichia coli. Microb. Cell Fact. 2009, 8, 1-18. [CrossRef]

127. Elsner, H.A.; Horn, P.A.; Schoenemann, C.; Altermann, W.W.; Blasczyk, R. Aberrant expression of hla-b*3565q is associated with a disrupted disulfide bond. Immunogenetics 2006, 58, 929-931. [CrossRef]

128. Wang, X.; Yuan, C.; Huang, B.; Fan, J.; Feng, Y.; Li, A.J.; Zhang, B.; Lei, Y.; Ye, Z.; Zhao, L.; et al. Developing a versatile shotgun cloning strategy for single-vector-based multiplex expression of short interfering rnas (sirnas) in mammalian cells. ACS Synth. Biol. 2019, 8, 2092-2105. [CrossRef]

129. Mavridis, K.; Wipf, N.; Medves, S.; Erquiaga, I.; Muller, P.; Vontas, J. Rapid multiplex gene expression assays for monitoring metabolic resistance in the major malaria vector anopheles gambiae. Parasites Vectors 2019, 12, 9. [CrossRef]

130. Li, T.; Liu, B.; Mao, W.; Gao, R.; Wu, J.; Deng, Y.; Shen, Y.; Liu, K.; Cao, J. Prostaglandin e2 promotes nitric oxide synthase 2, platelet-activating factor receptor, and matrix metalloproteinase-2 expression in escherichia coli-challenged ex vivo endometrial explants via the prostaglandin e2 receptor 4/protein kinase a signaling pathway. Theriogenology 2019, 134, 65-73.

131. Pazmino-Ibarra, V.; Mengual-Marti, A.; Targovnik, A.M.; Herrero, S. Improvement of baculovirus as protein expression vector and as biopesticide by crispr/cas9 editing. Biotechnol. Bioeng. 2019, 116, 2823-2833. [CrossRef] [PubMed]

132. Smolander, J.; Dehmer, M.; Emmert-Streib, F. Comparing deep belief networks with support vector machines for classifying gene expression data from complex disorders. FEBS Open Bio 2019, 9, 1232-1248. [CrossRef] [PubMed]

133. Yao, N.; Liu, J.Y.; Tian, Y.Y.; Dong, Y.Y.; Liu, X.M.; Li, H.Y. Cloning and expression analysis of ctbhlh transcription factor gene from carthamus tinctorius and construction of plant expression vector. Zhongguo Zhong Yao Za Zhi Zhongguo Zhongyao Zazhi China J. Chin. Mater. Med. 2019, 44, 278-282.

134. Zhao, J.Z.; Xu, L.M.; Liu, M.; Cao, Y.S.; Yin, J.S.; Liu, H.B.; Lu, T.Y.; Zhang, Z.Y. Identification of the optimal insertion site for expression of a foreign gene in an infectious hematopoietic necrosis virus vector. Arch. Virol. 2019, 164, 2505-2513. [CrossRef]

135. Zhu, X.H.; Peng, H.S.; Jiang, Y.L.; Wu, S.H.; Tang, S.Y.; Liu, Y.H. Construction of mouse ccr3 gene rnai lentivirus vector and its expression on mast cells]. Lin Chuang Er Bi Yan Hou Tou Jing Wai Ke Za Zhi J. Clin. Otorhinolaryngol. Head Neck Surg. 2019, 33, 628-634.

136. Xu, X.; Ding, H.; Liu, J.; Xia, W.; Deng, J.; Chen, Y.; Wang, J.; Shao, Y.; Chen, D.; Ye, X. Construction of eukaryotic expression vector for human platelet cd36 gene 220c $>t$ and 429+4insg variants and analysis of their expressions in hek293t cells. Zhonghua Yi Xue Yi Chuan Xue Za Zhi Zhonghua Yixue Yichuanxue Zazhi Chin. J. Med Genet. 2019, 36, 124-127.

137. Zhao, L.; Hu, X.; Li, Y.; Wang, Z.; Wang, X. Construction of a novel escherichia coli expression system: Relocation of lpxa from chromosome to a constitutive expression vector. Appl. Microbiol. Biotechnol. 2019, 103, 7177-7189. [CrossRef] 
138. Sandro, Q.; Relizani, K.; Benchaouir, R. Aav production using baculovirus expression vector system. Methods Mol. Biol. 2019, 1937, 91-99.

139. Takagi, S.; Tsutsumi, N.; Terui, Y.; Kong, X.; Yurimoto, H.; Sakai, Y. Engineering the expression system for komagataella phaffii (pichia pastoris): An attempt to develop a methanol-free expression system. FEMS Yeast Res. 2019, 19, foz059. [CrossRef]

140. Zhao, D.; Huang, Z.; Liu, J.; Ma, L.; He, J. Expression, purification, and characterization of n-terminal his-tagged proteins with mutations in zinc finger 3 of zinc finger protein znf191(243-368). Prep. Biochem. Biotechnol. 2018, 48, 914-919. [CrossRef]

141. Zhang, S.B.; Zhang, W.J.; Zhai, H.C.; Lv, Y.Y.; Cai, J.P.; Jia, F.; Wang, J.S.; Hu, Y.S. Expression of a wheat beta-1,3-glucanase in pichia pastoris and its inhibitory effect on fungi commonly associated with wheat kernel. Protein Expr. Purif. 2019, 154, 134-139. [CrossRef] [PubMed]

142. Li, X.D.; Zhou, L.J.; Zhao, C.; Lu, L.; Niu, N.N.; Han, J.X.; Zhao, K.H. Optimization of expression of orange carotenoid protein in escherichia coli. Protein Expr. Purif. 2019, 156, 66-71. [CrossRef] [PubMed]

143. Zheng, W.; Yang, L.; Cai, C.; Ni, J.; Liu, B. Expression, purification and characterization of a novel double-sites mutant of the single-chain sweet-tasting protein monellin (mnei) with both improved sweetness and stability. Protein Expr. Purif. 2018, 143, 52-56. [CrossRef] [PubMed]

144. Zheng, J.Y.; Lan, X.; Li, X.J.; Huang, L.J.; Zhang, Y.J.; Wang, Z. High-level expression and characterization of a stereoselective lipase from aspergillus oryzae in pichia pastoris. Protein Expr. Purif. 2019, 155, 1-7. [CrossRef] [PubMed]

145. Zhao, W.; Wang, Q.; Xu, Z.; Liu, R.; Cui, F. Distinct replication and gene expression strategies of the rice stripe virus in vector insects and host plants. J. Gen. Virol. 2019, 100, 877-888. [CrossRef]

146. Zhao, R.Q. Expression, purification and characterization of the plant snf1-related protein kinase 1 from escherichia coli. Protein Expr. Purif. 2019, 162, 24-31. [CrossRef]

147. Shi, X.; Cordero, T.; Garrigues, S.; Marcos, J.F.; Daros, J.A.; Coca, M. Efficient production of antifungal proteins in plants using a new transient expression vector derived from tobacco mosaic virus. Plant Biotechnol. J. 2019, 17, 1069-1080. [CrossRef]

148. Seyfi, R.; Babaeipour, V.; Mofid, M.R.; Kahaki, F.A. Expression and production of recombinant scorpine as a potassium channel blocker protein in escherichia coli. Biotechnol. Appl. Biochem. 2019, 66, 119-129. [CrossRef]

149. Retnoningrum, D.S.; Santika, I.W.M.; Kesuma, S.; Ekowati, S.A.; Riani, C. Construction and characterization of a medium copy number expression vector carrying auto-inducible dps promoter to overproduce a bacterial superoxide dismutase in escherichia coli. Mol. Biotechnol. 2019, 61, 231-240. [CrossRef]

150. Peng, B.; Xue, G.; Xu, D.; Feng, Z.; Chen, J.; Huang, M.; Lu, H.; Gong, L. Expression and purification of recombinant serine protease domain of human coagulation factor xii in pichia pastoris. Biosci. Biotechnol. Biochem. 2019, 83, 1815-1821. [CrossRef]

151. Amroudie, M.N.; Ataei, F. Experimental and theoretical study of ibc domain from human ip3r2; molecular cloning, bacterial expression and protein purification. Int. J. Biol. Macromol. 2019, 124, 1321-1327. [CrossRef] [PubMed]

152. Arjmand, S.; Tavasoli, Z.; Ranaei Siadat, S.O.; Saeidi, B.; Tavana, H. Enhancing chimeric hydrophobin ii-vascular endothelial growth factor a165 expression in pichia pastoris and its efficient purification using hydrophobin counterpart. Int. J. Biol. Macromol. 2019, 139, 1028-1034. [CrossRef] [PubMed]

153. Ballesteros-Briones, M.C.; Martisova, E.; Casales, E.; Silva-Pilipich, N.; Bunuales, M.; Galindo, J.; Mancheno, U.; Gorraiz, M.; Lasarte, J.J.; Kochan, G.; et al. Short-term local expression of a pd-11 blocking antibody from a self-replicating rna vector induces potent antitumor responses. Mol. Ther. J. Am. Soc. Gene Ther. 2019, 27, 1892-1905. [CrossRef] [PubMed]

154. Barkhordari, F.; Sohrabi, N.; Davami, F.; Mahboudi, F.; Garoosi, Y.T. Cloning, expression and characterization of a her2-alpha luffin fusion protein in escherichia coli. Prep. Biochem. Biotechnol. 2019, 49, 759-766. [CrossRef]

155. Bryant, W.B.; Mills, M.K.; Olson, B.J.; Michel, K. Small rna-seq analysis reveals mirna expression dynamics across tissues in the malaria vector, anopheles gambiae. G3 2019, 9, 1507-1517. [CrossRef]

156. Camara, E.; Monforte, S.; Albiol, J.; Ferrer, P. Deregulation of methanol metabolism reverts transcriptional limitations of recombinant pichia pastoris (komagataella spp) with multiple expression cassettes under control of the aox1 promoter. Biotechnol. Bioeng. 2019, 116, 1710-1720. [CrossRef] 
157. Carmignotto, G.P.; Azzoni, A.R. On the expression of recombinant cas9 protein in e. Coli bl21(de3) and bl21(de3) rosetta strains. J. Biotechnol. 2019, 306, 62-70. [CrossRef]

158. Huang, S.F.; Liu, D.B.; Zeng, J.M.; Xiao, Q.; Luo, M.; Zhang, W.P.; Tao, K.; Wen, J.P.; Huang, Z.G.; Feng, W.L. Cloning, expression, purification and functional characterization of the oligomerization domain of bcr-abl oncoprotein fused to the cytoplasmic transduction peptide. Protein Expr. Purif. 2009, 64, 167-178. [CrossRef]

159. Berkmen, M. Production of disulfide-bonded proteins in escherichia coli. Protein Expr. Purif. 2012, 82, 240-251. [CrossRef]

160. Santos, B.D.; Morones-Ramirez, J.R.; Balderas-Renteria, I.; Casillas-Vega, N.G.; Galbraith, D.W.; Zarate, X. Optimizing periplasmic expression in escherichia coli for the production of recombinant proteins tagged with the small metal-binding protein smbp. Mol. Biotechnol. 2019, 61, 451-460. [CrossRef]

161. Wei, X.; Wu, R.; Zhang, L.; Ahmad, B.; Si, D.; Zhang, R. Expression, purification, and characterization of a novel hybrid peptide with potent antibacterial activity. Molecules 2018, 23, 1491. [CrossRef] [PubMed]

162. Xie, Y.; Han, X.; Miao, Y. An effective recombinant protein expression and purification system in saccharomyces cerevisiae. Curr. Protoc. Mol. Biol. 2018, 123, e62. [CrossRef]

163. Jahangirizadeh, Z.; Ghafouri, H.; Sajedi, R.H.; Sarikhan, S.; Taghdir, M.; Sariri, R. Molecular cloning, prokaryotic expression, purification, structural studies and functional implications of heat shock protein 70 (hsp70) from rutilus frisii kutum. Int. J. Biol. Macromol. 2018, 108, 798-807. [CrossRef] [PubMed]

164. Li, N.; Yuan, D.; Huang, L.J. Development of a gateway-compatible two-component expression vector system for plants. Transgenic Res. 2019, 28, 561-572. [CrossRef]

165. Li, Q.; Chang, Z.; Oliveira, G.; Xiong, M.; Smith, L.M.; Frey, B.L.; Welham, N.V. Protein turnover during in vitro tissue engineering. Biomaterials 2016, 81, 104-113. [CrossRef]

166. Kikuchi, M.; Iwabuchi, S.; Kikkou, T.; Noguchi, K.; Odaka, M.; Yohda, M.; Kawata, M.; Sato, C.; Matsumoto, O. Expression, purification, crystallization and preliminary crystallographic analysis of hepatitis b virus core protein dimerized via a peptide linker containing an egfp insertion. Acta Crystallogr. Sect. F Struct. Biol. Cryst. Commun. 2013, 69, 942-945. [CrossRef] [PubMed]

167. Karakas-Sen, A.; Narbad, A. Heterologous expression and purification of nisa, the precursor peptide of lantibiotic nisin from lactococcus lactis. Acta Biol. Hung. 2012, 63, 301-310. [CrossRef] [PubMed]

168. Johnson, T.; Koria, P. Expression and purification of neurotrophin-elastin-like peptide fusion proteins for neural regeneration. BioDrugs Clin. Immunother. Biopharm. Gene Ther. 2016, 30, 117-127. [CrossRef]

169. Huo, Y.; Wang, F.; Sun, B.; Yin, L.R.; Zhang, P.P.; Zhang, Y.J.; Zhang, B.M. Prokaryotic expression and purification of antimicrobial peptide ll-37 and the inhibiting effect against candida albicans. Zhonghua Fu Chan Ke Za Zhi 2016, 51, 120-125.

170. Huang, S.F.; Liu, D.B.; Zeng, J.M.; Yuan, Y.; Xiao, Q.; Sun, C.M.; Li, C.L.; Tao, K.; Wen, J.P.; Huang, Z.G.; et al. Cloning, expression, purification, distribution and kinetics characterization of the bacterial beta-galactosidase fused to the cytoplasmic transduction peptide in vitro and in vivo. Protein Expr. Purif. 2009, 68, 167-176. [CrossRef]

171. Hu, F.; Ke, T.; Li, X.; Mao, P.H.; Jin, X.; Hui, F.L.; Ma, X.D.; Ma, L.X. Expression and purification of an antimicrobial peptide by fusion with elastin-like polypeptides in escherichia coli. Appl. Biochem. Biotechnol. 2010, 160, 2377-2387. [CrossRef] [PubMed]

172. He, Q.; Fu, A.Y.; Li, T.J. Expression and one-step purification of the antimicrobial peptide cathelicidin-bf using the intein system in bacillus subtilis. J. Ind. Microbiol. Biotechnol. 2015, 42, 647-653. [CrossRef] [PubMed]

(C) 2020 by the authors. Licensee MDPI, Basel, Switzerland. This article is an open access article distributed under the terms and conditions of the Creative Commons Attribution (CC BY) license (http://creativecommons.org/licenses/by/4.0/). 